Review

\title{
Vestiges of the Pre-Caledonian Passive Margin of Baltica in the Scandinavian Caledonides: Overview, Revisions and Control on the Structure of the Mountain Belt
}

\author{
Torgeir B. Andersen ${ }^{1, *(\mathbb{C}}$, Johannes Jakob ${ }^{1,2}$, Hans Jørgen Kjøll ${ }^{1,3}{ }^{-0}$ and Christian Tegner ${ }^{4}$ \\ 1 The Centre for Earth Evolution and Dynamics (CEED), University of Oslo, Blindern, P.O. Box 1047, \\ NO-0316 Oslo, Norway; Johannes.Jakob@NGU.NO (J.J.); h.j.kjoll@geo.uio.no (H.J.K.) \\ 2 Geological Survey of Norway, Torgarden, P.O. Box 6315, NO-7491 Trondheim, Norway \\ 3 Department of Geosciences, University of Oslo, Blindern, P.O. Box 1047, NO-0316 Oslo, Norway \\ 4 Centre of Earth System Petrology, Department of Geoscience, Aarhus University, 8000 Aarhus, Denmark; \\ christian.tegner@geo.au.dk \\ * Correspondence: t.b.andersen@geo.uio.no; Tel.: +47-22856415
}

Citation: Andersen, T.B.; Jakob, J.; Kjøll, H.J.; Tegner, C. Vestiges of the Pre-Caledonian Passive Margin of Baltica in the Scandinavian Caledonides: Overview, Revisions and Control on the Structure of the Mountain Belt. Geosciences 2022, 12,

57. https://doi.org/10.3390/ geosciences 12020057

Academic Editors: Rodolfo Carosi, Mario da Costa Campos Neto, Haakon Fossen, Chiara Montomoli, Matteo Simonetti, Olivier Lacombe and Jesus Martinez-Frias

Received: 29 November 2021

Accepted: 21 January 2022

Published: 25 January 2022

Publisher's Note: MDPI stays neutral with regard to jurisdictional claims in published maps and institutional affiliations.

Copyright: (C) 2022 by the authors. Licensee MDPI, Basel, Switzerland. This article is an open access article distributed under the terms and conditions of the Creative Commons Attribution (CC BY) license (https:// creativecommons.org/licenses/by/ $4.0 /)$.

\begin{abstract}
The Pre-Caledonian margin of Baltica has been outlined as a tapering wedge with increasing magmatism towards the ocean-continent transition. It is, however, well known that margins are complex, with different and diachronous evolution along and across strike. Baltica's vestiges in the Scandes have complexities akin to modern margins. It included a microcontinent and magma-poor hyperextended and magma-rich segments. It was probably up to $1500 \mathrm{~km}$ wide before distal parts were affected by plate convergence. Characteristic features are exhumed mantle peridotites and their detrital equivalents, some exposed to the seafloor by the pre-orogenic hyperextension. A major change in the architecture of the mountain belt occurred across the NW-SE trending Sveconorwegian front in the Baltican basement. This coincided with the NE termination of the Jotun-Lindås-Dalsfjord basement nappes, the remains of the Jotun Microcontinent (JMC) formed by hyperextension prior to the orogeny. Mantle with ophicalcite breccias exhumed by hyperextension are covered by deepmarine sediments and local conglomerates. Baltican basement slivers are common in the transitional crust basins. Outboard the JMC, the margin was magma-rich. The main break-up magmatism at $605 \pm 10$ Ma was part of the vast Central Iapetus Magmatic Province. The along-strike heterogeneity of the margin controlled diachronous and contrasting tectonic evolution during the later Caledonian plate convergence and collision.
\end{abstract}

Keywords: Scandinavian Caledonides; Baltica; passive margin; hyperextension; mantle exhumation; microcontinent; magma-rich; magma-poor

\section{Introduction}

Intensive research and exploration in passive continental margins worldwide and particularly in transitions to the oceanic lithosphere, accompanied by evermore detailed studies in the vestiges of continental margins preserved within mountain belts, have radically improved the understanding of passive continental margins (e.g., [1]). Importantly, remnants of continental margins can be directly observed after fully developed Wilson Cycles within mountain belts, so also in the Scandinavian Caledonides. The well-preserved proximal rift basins now located in the foreland of the mountain belt in Scandinavia ('the sparagmite basins') have been studied in detail previously and we refer to reviews by Nystuen et al. [2] and Jakob et al. [3]. The link and evolution between the proximal and distal parts of the margin and its along-strike variation have been less well investigated, we review and discuss these here. Three factors are particularly important for the new understanding of the Pre-Caledonian margin's evolution, with magma-poor and magmarich segments, and Baltica's paleographical position during the rifting. 
Firstly, discoveries by direct observation from drilling, dredging and geophysical imaging off-shore have shown that subcontinental mantle, not uncommonly, may be exhumed to or nearly to the sea floor by extension during the rifting stage of the Wilson Cycle. This is observed in present-day submerged margins, and particularly in magmapoor margin segments [4-7]. Exhumed mantle has also been described and interpreted in magma-rich or transitional magma-poor/magma-rich segments such as in the present-day Norwegian-Greenland Sea [8,9]. Importantly, remnants of magma-poor margins have been studied and discussed in detail from several mountain belts, particularly in the European Alps and Corsica, in the Pyrenees, as well as from the Lower Palaeozoic Appalachian and Caledonian Orogens [10-17].

Second, major parts of passive margins worldwide developed magma-rich segments [18]. Their two-fold magma-poor-to-rich character demonstrates a large-scale along-strike variability that was not accounted for in the early Wilson Cycle models [19], as well as in recent models for the Pre-Caledonian margin of Baltica [2,20]. Present-day magma-rich margins are mostly submerged and, to a large extent, inaccessible for direct observations. A few partially exposed examples include the active Red Sea to Afar domain [21,22] as well as the older East Greenland and Labrador Sea margins [23]. Submerged present-day examples are numerous and portrayed in a number of geophysical studies worldwide (e.g., [24]). Ancient magma-rich margins are, however, rarely preserved in mountain belts after completed Wilson Cycles, most likely because the large volumes of mafic rocks increased the average crustal density so that they have mostly undergone near to complete subduction as a result of the additional densification by eclogitization during the late to terminal stages of Wilson Cycles. To our knowledge, the most complete example presently available for direct observation is the well-exposed but mostly deeply denudated rifted margin vestiges exposed along a large part ( 1000 km, Figure 1) of the Scandinavian Caledonides [25-28].

The third factor, particularly important for a new plate tectonic reconstruction of the Pre-Caledonian Baltican margin [29], are the observations globally that magma-rich margin in space and time are commonly associated with voluminous break-up-related magmatism in Large Igneous Provinces (LIPs). Examples from the present Atlantic Ocean include the Paraná-Etendeka LIP of the South Atlantic, the Central Atlantic Magmatic Provinces (CAMP) and the North Atlantic Igneous Province (NALIP). Most geodynamicists, supported by petrological evidence, agree that the basalt-dominated magmatism in LIPs is triggered by the arrival of mantle plumes producing excess base lithosphere temperatures of up to $200{ }^{\circ} \mathrm{C}$ and causing large-scale melting of the upper mantle [29-33]. These observations can be used to develop plate tectonic reconstructions with respect to the mantle throughout the Phanerozoic [34,35] and now into the Neoproterozoic [29]. Pre-Pangea plate reconstructions are based on paleomagnetically constrained latitude of LIP eruption centers on the Earth's surface at the time of their eruptions, and their reconstructed positions directly above the Plume-Generation Zones (PGZ) along the edges of large low-shear-wave-velocity provinces (LLSVPs) in the lowermost mantle [34]. The LIP(s) associated with the inception of the Caledonian-Appalachian Wilson Cycle is known as the Central Iapetus Magmatic Province (CIMP) [36]. In the Scandinavian Caledonides, this is expressed as the Scandinavian Dyke Complex (SDC) [29]. The Ediacaran CIMP is preserved mostly as very large dyke and widespread intrusive and minor volcanic complexes in NE North America and NW Europe. Importantly, it also intruded the autochthonous Baltican (and Laurentian) basement (Figure 1, Egersund Dykes (ED) at $616 \pm 5 \mathrm{Ma}$ ) in southern Scandinavia [37], providing a well-constrained palaeomagnetic pole for the SDC [38]. The plate reconstruction for the Ediacaran break-up and inception of Iapetus seafloor spreading is based on the LLSVP-PGZ-LIP model, as discussed in detail by [29]. The most intense SDC magmatism took place at $603 \pm 12 \mathrm{Ma}$ (see summary of ages in [27]) with late-stage and locally intense magmatism at $570 \mathrm{Ma}$ and $580 \mathrm{Ma}$ in the Seiland Igneous Province (SIC) and in the Fen-Alnö Peralkaline complexes, respectively [39-42]. It is worth noting that this break-up-related magmatism is distinctly older than the preserved intra Iapetus oceanic 
and arc magmatism $(\sim 500 \mathrm{Ma})$, and apparently also older than the hyperextension that took inboard of the JMC (see below).

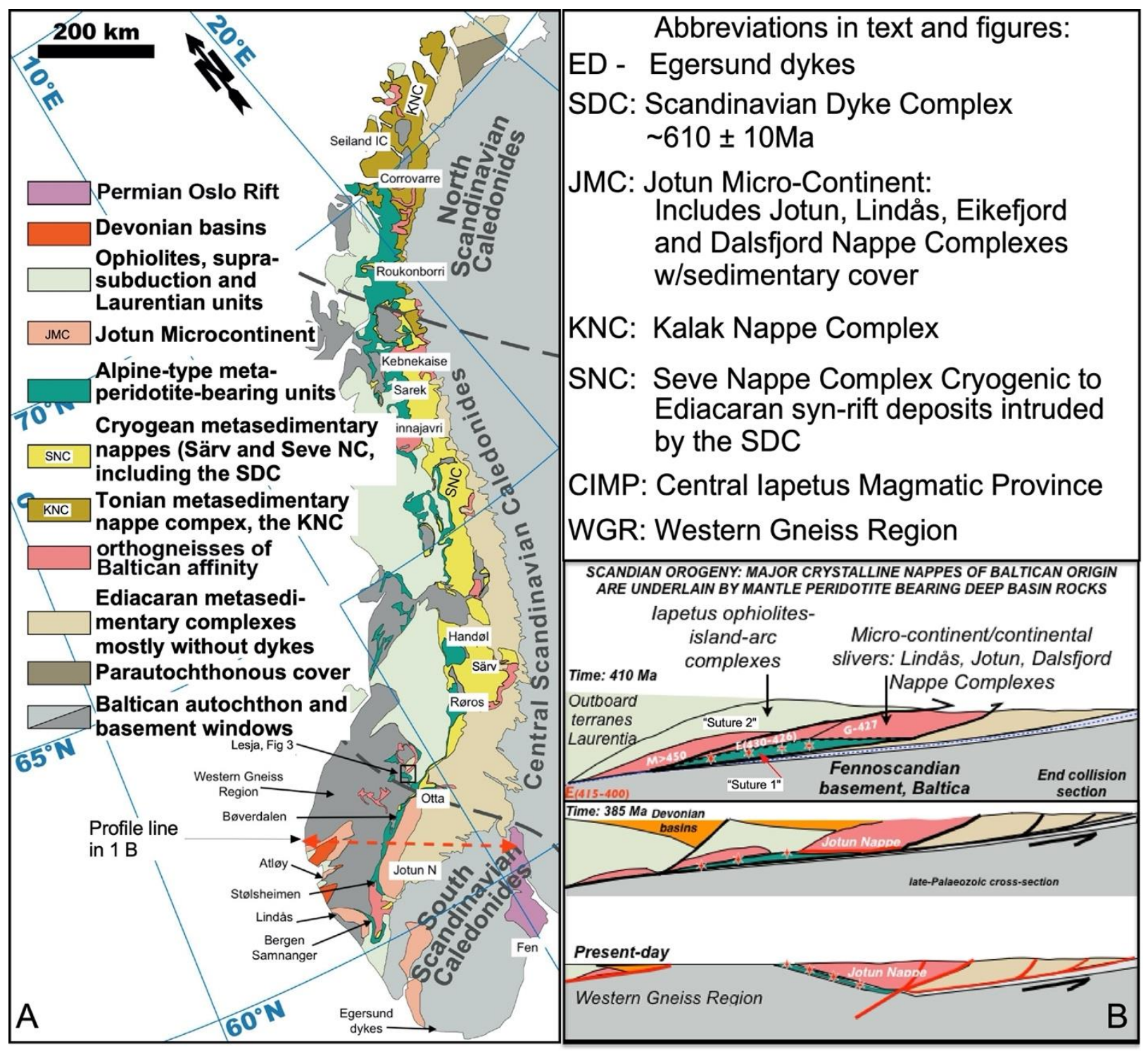

Figure 1. (A) The regional map and all abbreviations used in figures and text. (B) The evolutionary interpretation in a cross-section across of the Scandinavian Caledonides in South Norway (red-dotted line in (A)). The cross-section interpretations in (B) illustrate the suggested evolution from present-day observations (base) to the end-collision stage of the Scandian Orogeny at 410 (top) and at $385 \mathrm{Ma}$ (middle). Notice the pronounced late- to post-orogenic modification of the collisional geometry after the Scandian collision. Red stars mark the presence of the metaperidotites exhumed prior to the Scandian Collision. Numbers in white (G-427, E-430-426, M > 450) show ages (in Ma) of granite (G) intrusions and high-pressure metamorphism (M, phengite cooling age), respectively. Suture 1 and Suture 2 in the top (B) panel refer to previous interpretation of the metaperidotite-bearing unit and the Iapetan oceanic units in Ref. [43]. The map legend in panel (A) is shown in tectono-stratigraphic order (base to top). Notice that allochthonous Baltican basement is found both below and above the metaperidotite-bearing unit in the South Scandinavian Caledonides. Dashed lines mark the boundaries between the South, Central and North Caledonides, also used in previous studies and works in progress.

In view of the wealth of new information concerning the architecture, segmentation and dynamic evolution of rifted continental margins in general, and particularly along their 
ocean-continent transitions, we review the Pre-Caledonian margin of Baltica. The new results and interpretations have matured in research carried out at two Norwegian Research Council (NFR) Centres of Excellence, the Physics of Geological Processes (PGP) and the Centre of Earth Evolution and Dynamics (CEED), and have recently (2016-2019) been the focus in the NFR project 'Hyperextension in the Pre-Caledonian Margin of Baltica'. The new work was mainly concentrated in the rock complexes interpreted to have formed outboard of the margin's necking zone, whereas the proximal rift basins have been studied in great detail previously (see review in [2]). The link between the proximal domain and the structurally and metamorphic more complicated distal parts in the Caledonides was previously not well understood and is summarized here together with the along-strike variation.

\section{New Tectonic Models: From 'Dismembered Ophiolites' to Mantle Exhumation and Formation of Microcontinents by Rifting and Hyperextension}

The first suggestion that the largest Proterozoic crystalline basement nappe complexes in the Caledonides, the Jotun-Lindås-Dalsfjord and Eikefjord Nappe Complexes (JNC) of South Norway, constitute the remnants of a former microcontinent was proposed by [43]. As shown in the discussion and conclusions below, these authors suggested that the crystalline nappes rifted away to be separated by an oceanic basin from their ancestry in Baltica in the latest Proterozoic to Early Palaeozoic. They referred to the large allochthonous basement nappes and associated sedimentary cover as the Jotun Microcontinent (JMC, Figure 1). This suggestion was based on the recognition of the nearly continuous distribution of so-called 'dismembered ophiolites' found structurally below the JMC from the Bergen area in the SW across central South Norway to the Røros area (Figure 1). The 'ophiolitic rocks' in this tectonic unit are dominated by metaperidotites, and have only a minor volume of mafic rocks [43], one dated as Late Cambrian, $487 \pm 1 \mathrm{Ma}$ [44]. The remnants of this 'oceanic-type basin' inboard and below the JMC are referred to as 'Suture 1'. The wellpreserved Caledonian 'Penrose-type' ophiolites and their associated large Cambrian to Silurian Island arc sequences, representing closure of the main Iapetus Ocean, are positioned structurally above the JMC [45-47]. The ophiolite island arc unit is referred to as 'Suture 2' [43], and also hosts the occurrences of the Lower to Middle Ordovician Laurentian faunas in the Scandinavian Caledonides [48-50].

In the widely used 1985 structural template model for the Scandinavian Caledonides, all the allochthonous units were assigned to Lower, Middle, Upper and Uppermost Allochthons [51] (Roberts and Gee, 1985). These tectonic units were later interpreted as Baltican, Iapetan and Laurentian tectonic terranes [52]. Therefore, the presence and significance of two sutures at different structural levels, separated by a very large slice of mostly intact Proterozoic Baltican crystalline basement (the JMC) and cover, did not comply with the 1985 model. This problem was, however, mostly ignored until a new model for the Pre-Caledonian margin of Baltica was suggested by Andersen et al. [15]. The two-suture problem was further discussed in the review in Corfu et al. [53], who pointed out that the 1985 'lower to uppermost' structural template should be revised or preferably abandoned because it hindered a new understanding of the Scandinavian Caledonides.

The new interpretation of 'Suture 1' (Figure 1B) as a transitional crust basin, below and inboard of the JMC [15], came as a response to the much-improved understanding of continental rifting and exhumation of mantle by hyperextension that emerged after the discovery of exhumed mantle in present-day passive margins [7]. These new discoveries had also triggered re-interpretations of the 'Alpine type ophiolite/peridotites' in the type areas of the Alps and the Pyrenees $[10,12,14,54]$. The emergence of a new margin model provided a whole new explanation for the solitary 'Alpine peridotites' and the enigmatic 'dismembered, peridotite dominated ophiolitic complexes'. It also explained the intimate association of mantle rocks with continentally derived coarser-grained sediment [55] and slivers of Proterozoic basement in the Caledonides [15,44]. The hyperextension model implied that the 'dismembered ophiolitic' complexes had never been Penrose-type oceanic crust, but instead were emplaced structurally by extensional tectonics and exhumation of 
the mantle rocks, rather than being 'dismembered' by deformation during plate convergence and orogeny. This model also explained the stratigraphic relationships of solitary metaperidotites, ultramafic breccias and reworked detrital peridotites, as well as their association with the surrounding quartz-rich metasediments and slivers of crystalline basement. Furthermore, it was shown that all dated slivers of crystalline basement within 'Suture 1' had typical Baltican ages substantiating their origin as slivers and extensional allochthons derived from Baltica [44].

Following the original suggestion with two sutures (see above), Roberts [56] and Nilsson and Roberts [57] followed up the idea, suggesting an outboard 'cryptic arc or microcontinent' to explain their 'Eastern and Western Seaways', respectively. The model was also used to explain Baltican vs. Laurentian fauna provinciality and the diachronous (Ordovician and Siluro-Devonian) orogenic events in distal and proximal parts of the Scandinavian Caledonides [56,58-60]. Survey mapping (NGU, Geological Survey of Norway) along the NE-ward continuation of this transitional crust unit revealed a number of detrital peridotites, metaperidotite and soapstones (also referred to as dismembered ophiolites) in a number of NGU reports and by Nilsson and Roberts [57]. This NGU mapping and Jakob et al. [3] show that the 'ophiolitic rocks' have increasing volumes of gabbro, dykes and meta-basalts NE-wards from the Otta area (Figure 1). These ophiolitic complexes in strike continuum with the transitional crust basin are, however, positioned structurally below both the JMC and the ophiolite island arcs with Laurentian faunas of the Trondheim region $[3,47,56]$. From this area in the central Scandes, the metaperidotite-bearing unit can be mapped NE-wards (Figure 1). Here, it overlies the magma-rich margin segment containing the Late Neoproterozoic to Ediacaran sediments of the Seve Nappe Complex (SNC) truncated by the $\sim 600$ SDC dolerites. The metaperidotite-bearing unit marks the transition between Baltican rocks below and the outboard island arcs, ophiolites and associated sediments above. This contact is commonly referred to as the 'Seve-Køli' boundary (see Figure 1 and below), and in the present study, it is defined as a separate tectonic unit and referred to as an Alpine-type metaperidotite-bearing unit (Figure 1).

Compositionally, the metaperidotites, also referred to as 'primitive ultramafites' by Stigh [61], mainly represent depleted mantle (Figure 2, harzburgite and dunite) [62,63]. Some meta-dunites have cumulate and podiform chromite layers (Figure 2G). Importantly, they were affected by pre-orogenic carbonatization (ophicarbonate metasomatism) and widespread alteration to serpentinite and soapstone (Figure 2B, C) [64,65]. The general shortage, and in many cases, absence, of mafic igneous rocks distinguishes these metaperidotites from those commonly found in the Caledonian and Penrose ophiolites $[45,66]$. Exhumation of lithospheric mantle to the seafloor, where sedimentation was dominated by deep-marine deposits, is indicated by their association with original black shales (now graphitic mica-schists and phyllites). Already at the early exhumation stage, the peridotites were affected by widespread pre-orogenic metasomatic alteration and transformed into variably carbonated ophicalcite and soapstone breccias (Figure 2) [15]. The fragmentation into breccias took place by faulting and ductile shearing. Breccias and pseudo-sediments from the mantle rocks were in many instances reworked to detrital metaperidotites, and are now found as monomict conglomerates and sandstones (Figure 2C,D and Figure 3B) $[15,44,64]$. Ophicarbonate pebbles are commonly found in these detrital serpentinites/peridotites (Figure 2D). 


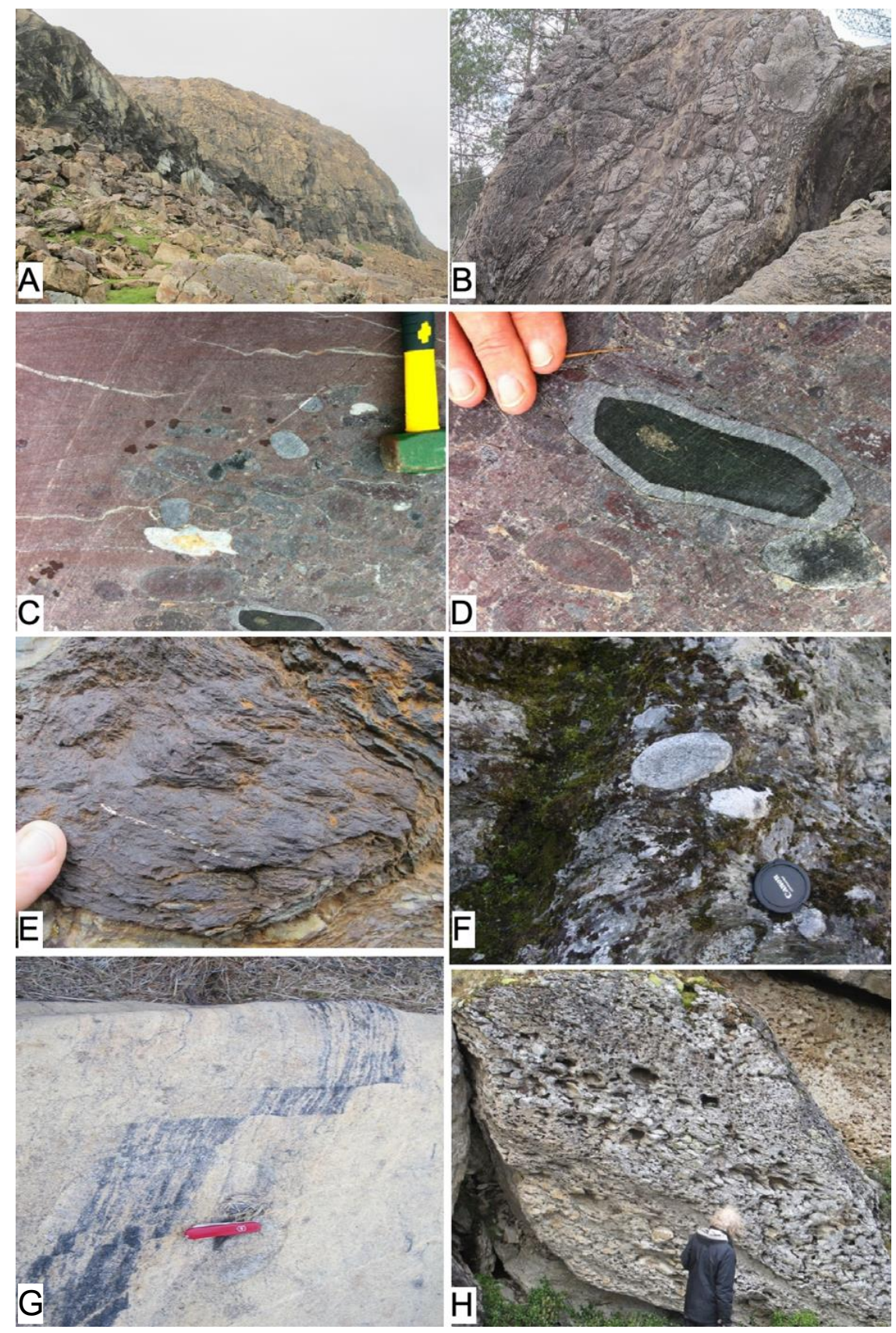

Figure 2. Photos from metaperidotite-bearing unit with Alpine-type metaperidotites formed inboard of, and now structurally below, the Jotun Microcontinent. (A) A view from the south of the km-sized Rauberget metaperidotite mostly composed of meta-dunite and meta-harzburgite in the Stølsheimen area (see map Figure 1). (B) Metaperidotite breccias with ophicalcite alteration (yellow/brown seams) at Samnanger. (C) Bedded metaperidotite conglomerate and ultra-mafic coarse-grained sandstone. Notice also white to yellow ophicalcite clasts and the well-rounded character of the fragments. Notice also the concentrically zoned (core-dunite (brown), green serpentinite, gray soapstone) peridotite clast, shown in more detail in panel (D). Hammer for scale in (C) is $30 \mathrm{~cm}$ long. Locality near Otta. (E) Rusty sulfide-rich (pyrrhotite) shale from the metaperidotite-bearing unit at Bøverdalen. Notice a thin seam of shiny pyrite. (F) Conglomerate with vein quartz and a dated granite clast ( 1330 Ma), from Stølsheimen. (G) Meta-dunite with faulted chromite layers, Samnanger-Bergen area. (H) Fan conglomerates with up to $30 \mathrm{~cm}$ quartzite and dolomite clasts (weathered holes) at Bøverdalen. For location of all photos, see Figure 1. 

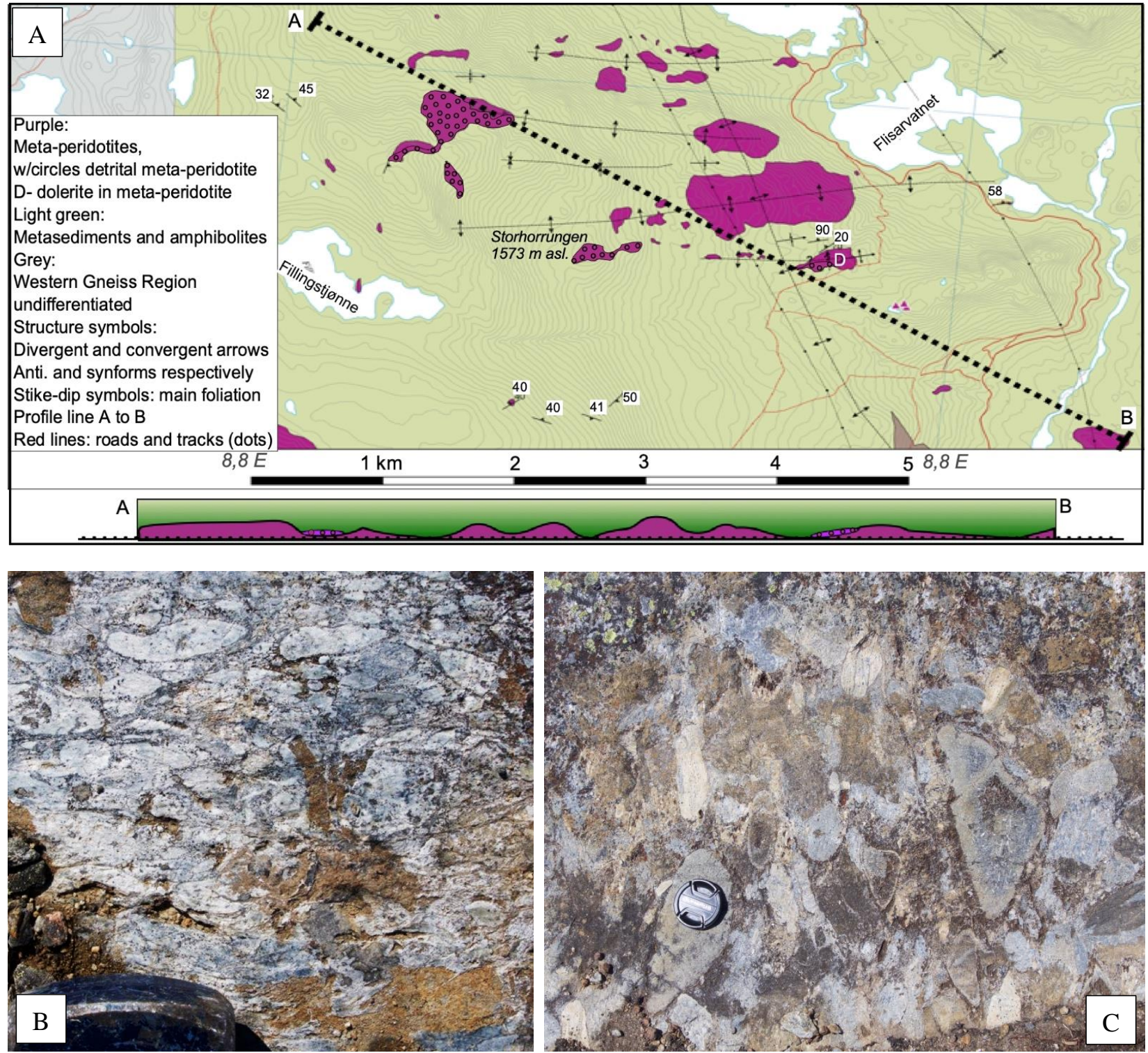

Figure 3. (A) Map with profile (dotted line) from the magma-poor to magma-rich transition zone near Lesja (Figure 1 for location). Notice that metaperidotites crop out along the hinges of Late Scandian E-W antiforms. Some have rims of metaperidotite breccias and detrital metaperidotites are shown as bright purple in the cross-section. (B) Peak-Scandian metamorphic mega-porphyroblasts (brown) of forsterite (Fo93) overgrowing an already-hydrated and carbonated detrital soapstone conglomerate with rounded pebbles/cobbles. Hammer head for scale is $15 \mathrm{~cm}$. (C) A metaperidotite (fault?) breccia with angular fragments. Notice the concentric alteration of fragments, and notice also that the brown, weathered olivine crystals overgrow the fragments and matrix shown in both panels. Mapping by J. Jakob, G. Mohn and O. Quintela.

The sedimentary matrix was originally fine-grained sediments, including graphiticand locally sulfide-rich shales (now phyllites/mica-schists) and some distal turbidite deposits (Figure 2E). The mostly fine-grained sedimentation was intermittently interrupted by coarser-grained 'single to multiple events' depositing quartz-rich and partly pebbly sandstone and locally coarser-grained fan-type conglomerates (Figure $2 \mathrm{H}$ ). The fanglomerates have rounded quartzite and vein-quartz fragments up to $\sim 30 \mathrm{~cm}$ in size, indicative of (re)deposition from a mature continental source. Well-rounded granite basement pebbles are also locally present (Figure 2F). One of these was dated (U/Pb zircon) to have a typical Sveconorwegian, Baltican age ( 1033 Ma, [15]). Pebbly sandstones with well-rounded 
vein-quartz and quartzite clasts have the characteristics of being redeposited from a highenergy environment. Some dolomite fragments, however, are flake-like (m-size), thin and angular, and most likely represent intra-formational clasts. The character of these coarsegrained deposits that locally invaded the deep basin sediments suggest that they were related to erosive mass-flow/density currents that channeled and redeposited material from structural highs, near-shore areas or islands into basins dominated by deep-marine shale to silty deposits. The black shale background sedimentation formed at reducing conditions is locally associated with sulfide (pyrite/pyrrhotite) enrichment, indicating some hydrothermal activity.

A large number $(>100)$ of meter to kilometer-scale solitary metaperidotites are in some cases rimmed by detrital peridotites (Figure 2). In one particularly well-preserved locality near Otta (Figure 1), a detrital serpentinite conglomerate has well-preserved fossils of Early to Mid-Ordovician age ( $470 \mathrm{Ma})$. This was described as an island-type fauna, also referred to as 'Celtic' by Harper et al. [67]. These observations show that already-hydrated mantle with serpentinite, soapstone and ophicalcite may most likely have formed protrusions to shallow water depths or that they may even have formed islands, similar to the presentday Zabargad Island of the Red Sea [68]. The insular 'Celtic' fauna suggests that it was well-separated from both Baltica and Laurentia in the Early to Middle Ordovician. Detrital serpentinites, some with less well-preserved fossils (gastropods), also occur in the strike continuation of the metaperidotite-bearing unit into Sweden [61]. Clastic serpentinites and soapstones are also found to the SW, in the Stølsheimen and Bergen areas (Figure 1) structurally below the Jotun and Lindås Nappe Complexes, former parts of the JMC (Figure 1B), but fossils have not been described from these occurrences.

Some of the metaperidotite breccias have angular fragments and most likely represent original fault or detrital fault scarp breccias (Figure 3B). Most are, however, crystalline metaperidotite bodies that are variably reworked by ductile-brittle shearing and now appear as 'pseudo-conglomerates' (Figure 2B). Transitions from massive metaperidotite to reworked breccias with variably rounded fragments to detrital metaperidotites are observed $[15,44]$. Concentric zoning of the fragments, with transitions from peridotite via serpentinite to soapstone, are common in all these examples with angular to rounded fragments (Figure 2C,D). Some have red cherty rims (jasper) similar to conglomerate pebbles, described by Beinlich et al. [69]. Redeposited ophicalcite fragments occur in the conglomerates, demonstrating pre-orogenic ophicarbonate alteration of exhumed mantle (Figure 2B,D). Adjacent sediments may also be affected by 'black-wall' metasomatism, and may have an enrichment of $\mathrm{Mg}$ and $\mathrm{Cr}$, seen as actinolite, fuchsite and rarely also uvarovite garnet set in quartz-rich horizons in the vicinity of metaperidotite bodies [3,70-73].

The metaperidotites, particularly the originally porous breccias and detrital metaperidotites, were strongly affected by pre-orogenic metasomatism (Figure 3B). Many are ophicarbonates, soapstones and serpentinites. Soapstones and talc schists have commonly been quarried since the Middle Ages until the present for talc and building/ornamental stone purposes and the deposits are now mostly emptied/exhausted in southern Scandinavia. The exhumation-related metasomatism is overprinted by the Caledonian medium- to high-grade metamorphism $\left(\mathrm{T}_{\max }-670{ }^{\circ} \mathrm{C} ; \mathrm{P}_{\max }-9.2 \mathrm{kbar}\right)$ affecting both the metaperidotites and the sedimentary matrix [64,74-76]. The most spectacular expression for the Scandian metamorphic overprint is very large (up to $\sim 0.25 \mathrm{~m}$ ) olivine crystals ( $\mathrm{Fo}_{90-95}$ ) that overgrow soapstones, detrital serpentinites and (fault?) breccias near Lesja (Figure 3). Regional metamorphic olivine also occurs in the Stølsheimen area, but similar large crystals are not observed here $[63,76,77]$. The fine-grained sedimentary matrix also contained organic carbon, which, together with petrogenetic modelling by the Theriak-Domino software, have been used to determine the $\mathrm{T}$ and $\mathrm{P}_{\max }$ (see above) and the regional prograde gradient of the Scandian metamorphism across South Norway [64,74]. This metamorphic zonation affected both the basal black shale and mica-schists along the Caledonian floor thrust as well as the metaperidotite-bearing unit. This gradient is continuous with the metamorphic gradient into the eclogite facies rocks of the Western Gneiss Region (WGR), which formed 
during the Scandian continental collision ( 415-395 Ma) [78]. It is important to point out that in all the studied localities, there are no differences in the regional Caledonian metamorphism of metaperidotites and their surrounding matrix meta-sediments. Consequently, there is no evidence of a Caledonian metamorphic hiatus between the exhumed mantle peridotites and adjacent metasediments [64]. Previous interpretations suggesting an Early Caledonian ('Finnmarkian') ophiolite obduction and metamorphism, followed by erosional denudation and a new orogenic cycle during the Scandian phase is therefore not supported by our observations in southern Norway, inboard of the JMC.

Unconformable relationships between the so-called 'dismembered ophiolites' and the surrounding sediments are here suggested to represent variably modified primary, non-conformable depositional contacts related to Pre-Scandian extensional tectonics and sedimentation in a mantle-floored basin, rather than to orogeny. However, a 482-474 Ma eclogite to amphibolite facies metamorphic event $[59,79]$ that is recorded in the Cryogenian metasedimentary complexes structurally below the Alpine metaperidotite-bearing units apparently did not affect the metaperidotites or the host rocks. As mentioned above, the metaperidotite-bearing unit (previously 'Suture 1' and Melange) contains a number of crystalline felsic to mafic basement slices. Several are U-Pb zircon dated as Mesoproterozoic $(1495,1229$ and $1154 \mathrm{Ma}$, two with secondary titanite that formed close to $1100 \mathrm{Ma}$, see Ref. [46]), which are typical ages of the Baltican basement in southern Scandinavia [80]. They vary in size from short, thin, small slivers ( 100 m scale) to more than $40 \mathrm{~km}$ in length [55]. It has been suggested that they represent original extensional slivers and allochthons of Baltican basement, inherited from the pre-orogenic hyperextension $[3,15]$. A scenario with extensional allochthons of thinned continental crust slivers forming structural highs and the source of siliciclastic sediments can be indicated. Such extensional allochthons may have separated deeper transitional crust basins with exhumed mantle. This model is similar to the observations from the Iberian and the NE Atlantic margin to the west of the British Isles, and was suggested as the best present-day analogue for parts of the Pre-Caledonian margin of Baltica inboard of the JMC [15].

\section{The Distal Margin of the Jotun Microcontinent (JMC) and the Magma-Poor to Magma-Rich Transition Zone}

We have argued for the existence of a seaway partly floored by exhumed mantle inboard of the JMC in the Early-Middle Ordovician [15]. Hence, the Pre-Scandian margin of Baltica was hyper-extended in-board the large $\left(>50,000 \mathrm{~km}^{2}\right) \mathrm{JMC}$ sliver. This also implies that the rifted Pre-Caledonian margin of Baltica was very wide, as was already suggested by Nystuen et al. [2] and discussed further by Jakob et al. [3] to be in the order of $\sim 1500 \mathrm{~km}$. Before describing the main magma-rich segment to the NE, it is necessary to briefly discuss the outboard margin of the JMC. This is only partially preserved in westernmost Norway, primarily in the Atløy area and near Bergen (Figure 1). Here, there is both stratigraphic and geochronological evidence (Figure 1, Atløy and Lindås/Bergen area) that the outboard margin of the JMC was subjected to a Pre-Scandian high-P and low-T (HP-LT) event, partly at eclogite facies, in the Middle/Late Ordovician to the Early Silurian [58,81-83]. This Pre-Scandian event did, however, not affect the eastern margin of the JMC nor the inboard metaperidotite-bearing unit. Ordovician (ultra) HP-LT event(s) also affected the magma-rich margin along the Seve Nappe Complex (SNC), as documented by several authors (e.g., [28,59,84-86]).

In the Atløy area (Figure 1), the distal JMC crystalline basement of the Dalsfjord and Eikefjord Nappes $[81,87]$ is non-conformably overlain by the $>5 \mathrm{~km}$ thick shallow-to-deepmarine syn- to post-rift deposits of the Høyvik Group [83,88]. Importantly, this basement cover pair was truncated by a pre-orogenic mafic dyke swarm. The uppermost parts of the Høyvik Group at Atløy (Figure 1) also have minor meta-basalt, locally with poorly preserved pillows [89]. This basement cover pair and the associated mafic dykes and lavas were affected by a Pre-Scandian deformation and HP greenschist metamorphism before $449 \pm 2 \mathrm{Ma}\left({ }^{40} \mathrm{Ar} /{ }^{39} \mathrm{Ar}\right.$ cooling age of phengite $\left.[58,90]\right)$. They were exhumed 
and unconformably overlain by the fossiliferous Middle Silurian (Wenlock, 433-427 Ma) Herland Group [83] before the main Scandian orogeny, which commenced after the final closure of the Iapetus and the obduction of the Solund-Stavfjord Ophiolite, in West Norway near Atløy (Figure 1A) [89,91]. The crystallization age of the pre-orogenic dyke swarm and lavas in the Atløy area are, however, not dated due to the Middle Ordovician and later Scandian deformation and metamorphic overprint. The MORB-type tholeiitic character and similarity with the dyke and wall-rock geology of the Seve and Särv equivalents (see below) suggest they were originally a part of the SDC-LIP $[29,59]$.

The NE termination of the JMC in South Norway coincides with the junction of the outboard magma-rich margin of the JMC and the magma-poor unit inboard of the JMC (Figure 1 and discussion/conclusions below). The metaperidotite-bearing unit NE of the JMC also comprises exhumed metaperidotites and detrital serpentinites. Importantly, mafic rocks including dykes, gabbros and lavas have become increasingly common to the NE. The rift-related metasandstone in the Seve Nappe Complex (SNC) and the Hummelfjell and Särv nappes (see also Figure 3 in Jakob et al. [3]) have long been recognized as characterized by pre-orogenic dolerite dyke swarms (see overview in [29]). It should, however, be pointed out that radiometric ages are not available for dykes cutting the metaperidotites in the Sjongseter Gp. of the transition zone near Lesja (Figure 3A) [76]. Previous mapping complemented by the present work demonstrates the gradual increase in the mafic magmatism in the Neoproterozoic units from Otta NE-wards into the Seve and Särv nappe complexes [3,92].

The rocks of metaperidotite-bearing unit have been studied in detail near Lesja (Figure 1), where a lithostratigraphic succession (local name: Sjongseter Gp.) comprises a basal sheet $(\sim 5 \times 2 \mathrm{~km})$ of mantle overlain by a mix of detrital metaperidotites and breccias, fine-to-medium-grained metasediments and amphibolite units [76]. The metaperidotites and siliclastic metasediments are truncated by mafic dykes and all rocks are affected by the high-grade Caledonian metamorphism [76]. Mapping of a $200 \mathrm{~km}$ long Neoproterozoic magma-poor to magma-rich transition segment NE of the JMC (Hummelfjellet, Seve, Särv nappes) shows that the metaperidotite-bearing unit is sandwiched between the Iapetus-derived ophiolite island arcs and the JMC above, and the Seve-Särv nappes and the proximal rift basins below [3,93]. The in-sequence stacking of the nappes and their lateral variation in content of mafic rocks demonstrate the gradual transition from the magma-poor inboard segment of the JMC to the magma-rich segment to the NE and outboard the JMC (see Figure 1 and discussion/conclusions below).

In several areas near Røros, at Handøl in Sweden and further to the north at Linnajavri (Figure 1), the metaperidotite-bearing unit comprises metaperidotite-dominated complexes previously interpreted as 'ophiolitic'. These are overprinted by the early metasomatism and later Caledonian metamorphism [65,70,72,93]. In the tradition of the so-called 'dismembered ophiolites', they were assigned to the 'Upper Allochthon' and as part of the so-called Køli nappes. They were hence regarded as outboard with respect to Baltica. Because of their geometrical position structurally below the well-established arc-complexes in the upper Køli nappes [52] and their similarity with the rock associations to the metaperidotitebearing unit described above, we suggest that they are better interpreted as a lateral continuation of the mantle-floored basin that apparently was an integral part of the BalticaIapetus rifted margin in the Ordovician. These exhumed mantle rocks, associated with detrital peridotites, are individually discontinuous and mostly smaller than one kilometer in length [61], but together, they constitute a laterally continuous unit over several hundreds of $\mathrm{km}$. The metaperidotite-bearing unit along the Seve Køli transition is underlain by the dyke-intruded Cryogenian to Ediacaran early syn-rift metasediments of the Seve, Särv and equivalent Nappe Complexes and is overlain by the outboard arc and ophiolites of the Iapetus (Figure 1).

As seen from Figure 1, the Scandinavian Caledonides incorporate a major change in the structural architecture at the NE termination of the JMC. This coincides approximately with the Middle Proterozoic, Sveconorwegian (Grenville) front ( 1000 Ma) in the Baltican 
basement (Figure 1 and discussion/conclusion below). Geophysical imaging of this major boundary in the Baltican basement shows that it also coincides with a change in the Moho depth of approximately $10 \mathrm{~km}$, from $40 \mathrm{~km}$ depth in the SW to $50 \mathrm{~km}$ in the NE [94]. It is likely that reactivation of this inherited Proterozoic basement structure in Baltica also influenced the Pre-Caledonian rifting and that it may have controlled the formation of the wide JMC promontory of the rifted margin of Baltica to the south of this basement structure. Consequently, the collision history and structural architecture Scandinavian Caledonides, with large remnants of the JMC in the south, were also influenced by Proterozoic basement inheritance.

\section{The Magma-Rich Segment of the Pre-Caledonian Baltican Margin: The Scandinavian Dyke Complex (SDC)}

The dyke-intruded Dalsfjord-Høyvik, Särv (SNC) and related nappes have been described by many authors [26,95-98] and recently in the present project [27,29]. The SNC is continuous NE-wards into northernmost Norway in Troms (Figure 4) and occurs locally structurally above the Kalak Nappe Complex (KNC). The KNC near Kvænangen is overlain by the SNC and in turn, the Reissa Nappe Complex. Gasser et al. [99] demonstrated a protracted Neoproterozoic deformation and high-grade metamorphism at $\sim 800$ to $700 \mathrm{Ma}$ in the Tonian paragneisses of the KNC in this area near Corrovarre (Figure 1). SDC dolerites are common at Corrovarre (Figure 1). Both the SNC metasediments and the KNC metasediments and paragneisses are floored by discontinuous sheets of MidProterozoic (in the south) and Paleo-Proterozoic to Archean crystalline basement sheets (in the north). Archean crystalline sheets at the base of the SNC near Corrovarre [100] are intruded by numerous (not-dated) mafic rocks (Figure 4). At Sarek, Kebnekaise and at Kvænangen near Corrovarre (Figure 1), the basal orthogneisses are overlain by the rift sediments [101]. Both crystalline basement and their syn-rift cover in the SNC were affected by Ediacaran extensional ductile deformation and local partial melting at 636 to $610 \mathrm{Ma}$ in the Corrovarre, Kebnekaise to Sarek areas [20,28,100-104]. The contacts between the orthogneisses and the syn-rift sediments are almost invariably shown on geological maps as thrusts (e.g., [26]). However, consistent 'young-on-old' relationships suggest they are original depositional contacts that are variably affected by the Pre-Caledonian extension, as shown by early kinematic indicators [27] as well as thrusting during the Caledonian nappe emplacement [26].

Although the SNC and the KNC apparently occupy a similar structural position in the Caledonian nappe sequence, a direct correlation of the Pre-Caledonian status of the rocks in these two nappe complexes cannot be upheld. In the SNC, detrital zircons give a maximum depositional age of the sediments in the Late Neoproterozoic after $~ 700 \mathrm{Ma}$. A tillite capped by a newly discovered stromatolitic dolomite is described from the Sarek area [101]. The SNC sedimentation, with clastic zircons as young as approximately $700 \mathrm{Ma}$ [101], indicate that the sedimentation was related to the Pre-Caledonian protracted Iapetus margin formation. In large parts of the KNC, however, lithologically similar metasandstonedominated units are much older, as indicated by comprehensive detrital zircon-age studies. Kirkland and co-workers have demonstrated that the sedimentation in units of the SNC commenced as early as $1080 \mathrm{Ma}$ and continued in other parts until approximately $850 \mathrm{Ma}$ [104-106]. Several parts of the KNC were affected by deformation, metamorphism and intruded by minor partial-melt granites cutting already deformed metasediments at approximately $850 \mathrm{Ma}[105,107]$. Details concerning the tectonics controlling this event are presently unknown. In the tradition that major deformational events involving ductile strains and metamorphism are related to plate convergence and accretion, it was assumed that the $850 \mathrm{Ma}$ event also represented collisional tectonics, which otherwise are not seen in Baltica [105,107]. An alternative model appealing to extensional tectonics accompanied by a high geotherm at $\sim 850$ Ma had, however, already been suggested by Paulsson and Andreasson [108]. These authors identified a similar-age intrusive event in a basement slice at Mårma near Kebnekaise in the SNC, where they dated (U/Pb zircon) crystallization of 
the Vistas granite at $845 \pm 14 \mathrm{Ma}$ with Archean-inherited zircons. The same authors [108] correlated the $\sim 850 \mathrm{Ma}$ ages from the SNC and KNC, and suggested they represented an early attempt of break-up within Rodinia. Incidentally, these $850 \mathrm{Ma}$ ages in the far north are also coincident with the Hunnedalen dolerite dyke swarm intruding autochthonous Baltican basement in the Egersund area of southwest Norway [109]. Kjøll [100] also dated gabbro and a high-T coronitic granulite at Mårma associated with the Vistas granite of the SNC and obtained U/Pb zircon 850-835 Ma ages, similar to those presented by Paulsson and Andreasson [108]. Other authors [106,107] used similar Late Proterozoic ages from the KNC, 'otherwise not found in Baltica' to suggest that both the KNC and SNC are exotic and likely 'Peri-Gondwana or Laurentian terranes accreted to Baltica during the Caledonian orogeny'. The tectono-thermal and intrusive histories of the older KNC sediments at approximately $850 \mathrm{Ma}$, however, suggest they are unrelated to the Pre-Caledonian Iapetus rifting, but may have been related to an earlier attempted rifting event in Rodinia. The relationships between the metasediments and the $606 \pm 2$ Ma dolerites of the SDC at Corrovarre [27] and the remaining part of the KNC to the NE are, at present, not resolved.

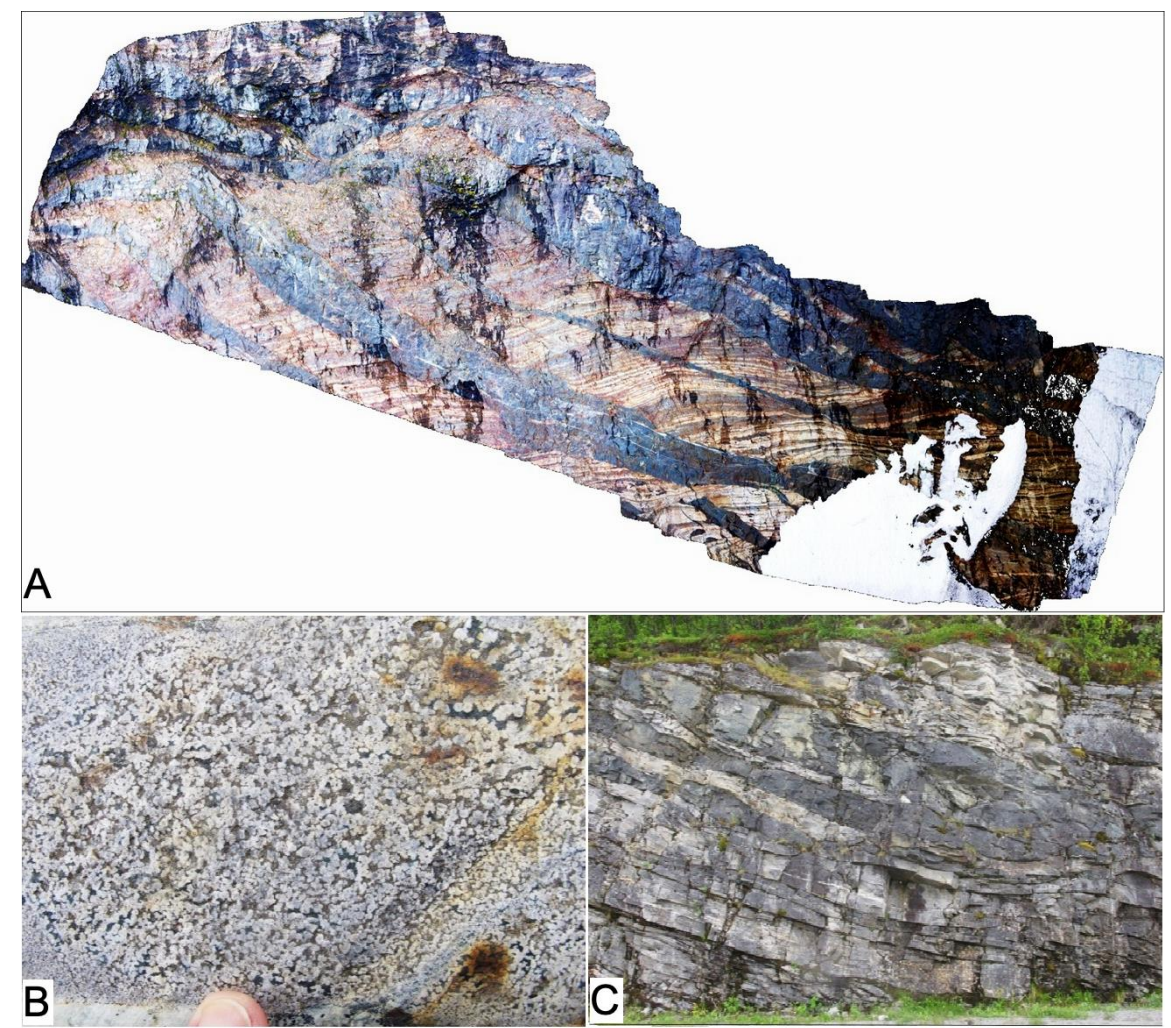

Figure 4. (A) Cliff wall partly draped by a glacier (to the right), at Rohkunborri National Park, showing Scandinavian Dyke Complex dolerites truncating Ediacaran syn-rift sediments of the Seve Nappe Complex. The stratigraphy is right-way-up and shows meta-evaporites (lower right), calcareous sandstones and sandstones (upper left). The image is a mosaic of 25 high-resolution geo-referenced drone images. The stratigraphic thickness shown from lower right to upper left is $\sim 140 \mathrm{~m}$ and the prominent dyke in the central lower part of the image is $\sim 7$ to $10 \mathrm{~m}$ thick (B) Details of a mafic dyke at Rohkunborri, cutting the meta-evaporites (contact at fingertip). The dyke is strongly metasomatized with the formation of pre-orogenic, static growth of $\mathrm{Cl}$-rich scapolite (Me 70 white crystals). This metasomatism reduces the rock density and hence also changes the petrophysical property of the basaltic rocks prior to later orogeny. (C) A $5 \mathrm{~m}$ high road section in felsic orthogneiss, intruded by numerous mafic sheets at the base of the Corrovarre lens in northernmost Norway. The felsic gneiss is Archean (see below and [92,100]), whereas the age of the mafic intrusives have not yet been dated. For locations of all images, see Figure 1. 
Syn-rift sediments of the SNC and at Corrovarre (Figure 1) have well-preserved and partly migmatitic hornfelses related to the intrusion of the $\sim 603 \mathrm{Ma}$ mafic dyke swarm of the SDC [28]. Both dykes and volcanics of the SNC are variably metamorphosed to garnet amphibolites and locally to eclogite facies [110]. In large areas, however, they are remarkably well-preserved with primary minerals and textures $[27,28,98,111,112]$. Where the dyke swarm truncates meta-evaporites in the rift sediments, many dolerites are metasomatically altered to contact metamorphic $\mathrm{Cl}$-rich scapolite rocks. The alteration of the SDC dolerites may vary across short distances from pristine, mostly fresh dolerite to scapolitized meta-dolerite (Figure 4B), amphibolite and locally eclogite. The lack of mineralogical equilibration across short distances $(10 \mathrm{~m}$ scale) in the SNC is similar to many observations from the (U)HP terrains of the JMC and the WGR in southwest Norway (e.g., [81,113]). These observations have, however, not yet been critically studied in the SNC. Rather, the P-max calculations have invariably taken to reflect original burial alone [83,114]. It is likely that the metamorphic contrasts, with or without eclogite facies rocks, across short distances observable in many areas of the SNC may have resulted in unrealistic interpretations of large-scale $(\mathrm{km})$ structural juxtaposition. In a recent paper, the regional significance of the UHP is questioned by Li et al. [115], who argue that a maximum-pressure regional metamorphism ( 0.8 to $1.4 \mathrm{GPa}$ ) represents the main burial depth of these rocks during the inception of Caledonian deformation along the Iapetus-Baltica margin. The 'standard SNC model', invoking large-scale thrust-stacking of three major internal nappe units within the $\mathrm{SNC}$, is probably strongly influenced by variation(s) in regional metamorphic pressure estimates rather than by quantitative structural analyses documenting large-scale localized shear strains.

Due to the Caledonian deformation, which included large-scale recumbent folding, several kilometer-long cliff sections are preserved, where dykes are sub-horizontal and sedimentary layering is steeply dipping to sub-vertical in these fold hinges (see [28] and Figure 4). This enables detailed observation of several $\mathrm{km}$ thick stratigraphic sections in the original magma-rich margin. The dykes have well-constrained radiometric ages (U-Pb on baddeleyite and zircon) in a number of localities from Särv in the south to Corrovarre in the north $(\sim 900 \mathrm{~km})$. Their average age is $\sim 603 \mathrm{Ma}$ (see references and summary in Kjøll et al. [27]).

The petrology and emplacement mechanism and history of the SDC are described by [27-29]. For full details, we refer to these studies. Tegner et al. [29] demonstrated that the SDC constituted a LIP, formed above a compositionally zoned mantle plume related to the CIMP, with enriched and depleted basalt magmas in the south and north, respectively. Kjøll et al. [27] showed that the dykes intruded at lithostatic pressures of 0.3 to 0,4 GPa, corresponding to depths of $\sim 10 \mathrm{~km}$, in the already-extended distal margin of Baltica. It was further shown that the magma emplacement rate was higher than could be accommodated by the tectonic extension alone, and that the margin underwent (local?) thickening up to $\sim 27 \%$ in addition to the expected horizontal extension [28]. Locally, the preserved dyke density across several kilometer-long sections is $70 \%$ to nearly $100 \%$ [25].

The stretching of the continental crust and emplacement of the voluminous LIP magmas gave rise to a high regional geotherm up to $70^{\circ} \mathrm{C} / \mathrm{km}$, which resulted in partial melting at $\sim 610 \mathrm{Ma}[20,27]$. Sheets of S-type granites at Corrovarre are truncated by the dykes of the SDC-LIP [27]. Lavas related to the dyke complex are only locally preserved as pillow basalts in the uppermost parts of the SNC [110] and at Atløy, West Norway (Figure 1 and [89]). Volcanics may be more common in the other parts of the SNC, such as in the Kebnekaise area, dominated by more deformed amphibolitic rocks and more pervasive Caledonian metamorphic recrystallization [116].

The SNC also comprises a large number of solitary mantle-derived metaperidotites $[61,85]$. Some have Early to Middle Ordovician (U)HP-LT assemblages [85,86,117]. These metaperidotites are different from those of the Linnajavri Complex, the Handöl 'ophiolite' and similar partly detrital metaperidotite complexes, which are lower grade and apparently unaffected by the Early Caledonian (U)HP metamorphism and associated with Ordovician 
sediments $[61,69,70,93]$. These metaperidotite bodies may have been juxtaposed with the Seve sediments along Edicaran mid-crustal extensional shear zones during crustal thinning, or these metaperidotite bodies are younger than the SDC magmatism in the SNC and may have been introduced from the hanging walls of deformation zone(s) along the distal northern margin of Baltica (Figure 5) that gave rise to the Early/Middle Ordovician metamorphism in the underlying parts of the SNC. Some solitary metaperidotites mapped as part of the Seve-Køli boundary are also rimmed by detrital metaperidotites, including local occurrences of fossiliferous serpentinite conglomerates [61]. The similarity with the metaperidotite-bearing unit further to the south is striking, and we suggest that it is likely that these complexes along the Seve-Køli boundary may also be of Ordovician in age. Therefore, we suggest that these bests are correlated with the metaperidotite-bearing unit in the south, and hence interpret those to be unrelated to the metaperidotites the SNC.

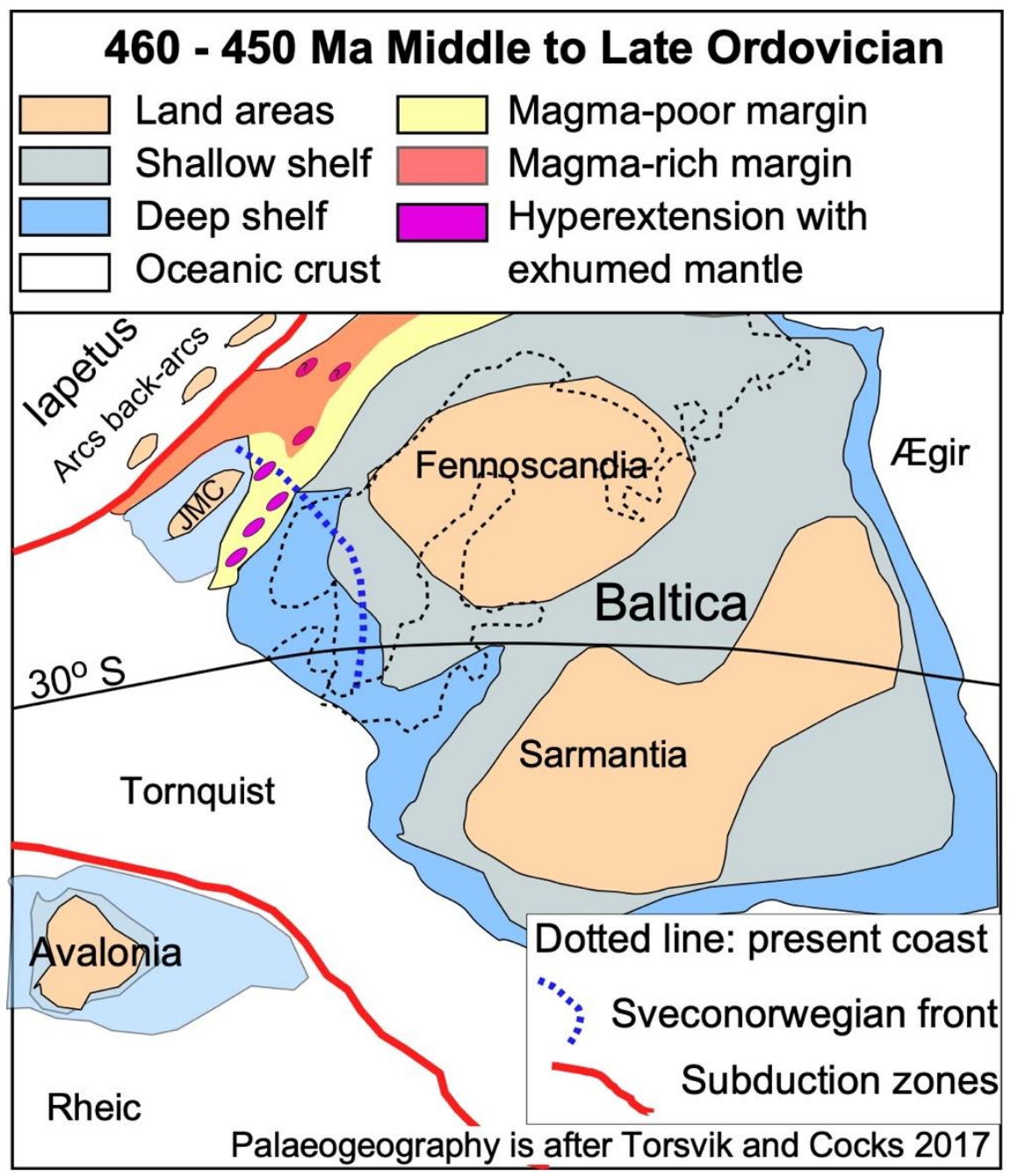

Figure 5. Regional Middle Ordovician plate reconstruction modified from [49], showing Early Caledonian subduction and arc-continent collision zones along the transitional crust basins(s) between the margin of Baltica and the Iapetus. Notice the distribution of the magma-rich and the magma-poor segments in yellow and red, respectively. Deformation along the margin probably started first in the north. Notice also the inboard Jotun Microcontinent (JMC) seaway with transitional crust and abundant mantle exhumation, shown by purple ellipses. The magma-rich margin segments are shown in red. Blue dotted line shows the approximate location of the Sveconorwegian front in the Baltican basement of Fennoscandia. This line coincides with the termination of the Jotun promontory and the transition from the magma-poor inboard JMC segment and the magma-rich outboard segment to the north and west. 
Because the metaperidotite-bearing unit in the lower Køli and the dolerite intruded SNC below occupy (1) a structural position, below the outboard ophiolite/island arc complexes and above proximal Baltican rift and platform sediments and (2) have similar lithologies and lithological association to those of the metaperidotite-bearing unit in the south, we suggest they formed part of a basin floored by transitional crust. Contrary to the metaperidotite-bearing unit inboard the JMC and those along the Seve-Køli boundary, the Late Neoproterozoic Ediacaran sediments outboard the JNC and of the SNC intruded by the SDC experienced Early Caledonian deformation and metamorphism prior to the Scandian continental collision. This suggests that the metaperidotite-bearing unit of the lower Køli was more outboard and situated in the hanging walls of the deformation zone(s) that developed along the ocean-continent transition between Baltica and Laurentia in the Ordovician (Figure 5). In this context, it is also important to note the metamorphic (zircon and rutile) ages of $473 \pm 3 \mathrm{Ma}$ from the Steinhø complex [79], which can be correlated with the SNC near the NE termination of the JMC (Figure 1). The outer margin of the JMC and the associated magma-rich complex were affected by an Early Caledonian event prior to $450 \mathrm{Ma}$, whereas the in-part mantle-floored basins inboard the JMC and in the hanging wall of the Ordovician subduction/collision zone remained unaffected by contractional deformation until the earliest Scandian collision. Pre-Scandian events, with a south to north diachroneity (older in the north), seem to have affected the Pre-Caledonian margin of Baltica in the Ordovician.

\section{Discussion}

As argued by Kjøll et al. [27], the main emplacement age of the LIP dykes of the SDC has an average age of $~ 603 \mathrm{Ma}$. Early- to late-stage magmatism of the CIMP also included the Egersund dykes at $615 \pm 5 \mathrm{Ma}$ in the south, and the large mafic-ultramafic SeilandIgneous Complex (SIC, Figure 1) at 570 to $560 \mathrm{Ma}$ in the north [37,41-43]. The peralkaline sub-volcanic plugs at Fen and Alnø can also tentatively be correlated with this plume event ( 580 Ma Figure 5). The metaperidotite-bearing units have been mapped inboard the JMC from the Bergen area for most of the Scandinavian Caledonides along the 'Seve-Køli boundary' to Finnmark in the north (Figure 1). We suggest that the Lower Køli Nappe is redefined as Alpine-type metaperidotite-bearing metasedimentary complexes, which can be traced from southwest Norway to Finnmark. The in-part mantle-floored basins either formed in the latest Cambrian to Early Ordovician or before, and received sediments at least into the Middle Ordovician. A magma-rich margin developed along the entire Iapetus margin of Baltica outboard the JMC and the SNC (Figure 5).

Detrital metaperidotites are the witnesses of hyperextension with exhumation of mantle to the seafloor. Hyperextension and exposure of mantle rocks at the Earth's surface took place in basins inboard the JMC (Figure 5). There is, however, no evidence and it is less likely that similar exhumation took place along the magma-rich parts of the margin, in the SNC and outboard the JMC. Mafic dykes truncating metaperidotites near Lesja (Figure 3A) were exposed to the seafloor (Figure 3B) before the Scandian Orogeny. Amphibolites of uncertain origin (dykes or volcanics?) are also intercalated with the metasediments (Sjongseter Gp.) overlying the metaperidotites in this area (Figure 3A). It should be noted that the depositional age of the Sjongseter sediments is unknown, but it is likely that they correlate with the fossiliferous sediments near Vågåmo and Otta. Consequently, it is suggested that the hyperextension inboard the JMC is younger than the formation of the magma-rich outer Iapetus margin of Baltica, and that the relatively sparse mafic magmatism in the peridotite-bearing transitional crust basins may be unrelated to the emplacement of the SDC. The metaperidotite-bearing unit structurally below the JMC continues directly into the metaperidotite-bearing unit of the Lower Køli structurally positioned above magmarich segment in the SNC (Figure 5). Similarly, the Sjongseter Group overlies dyke-intruded Neoproterozoic coarse-clastic sediments equivalent to the SNC or Särv nappe [92].

Early to Middle Ordovician deformation and metamorphism apparently affected the entire Neoproterozoic units of the distal Baltican margin, outboard the JMC and along 
the magma-rich margin of the SNC as far as Corrovarre. Dating of the Early Caledonian metamorphic events suggests that the orogenic activity occurred $~ 480-474 \mathrm{Ma}[59,79]$ in Neoproterozoic units of the SNC. Metamorphism of the Neoproterozoic outer margin of the JMC is constrained by (phengitic) mica cooling ages to $450 \mathrm{Ma}$ [58]. The Early Caledonian history of the KNC in Finnmark and its relationship to the SNC and JMC is, however, still unresolved.

The timing of hyperextension and mantle-exhumation inboard the JMC and in the units of the Lower Køli is less well constrained. The Ediacaran rifting accompanied by mantle exhumation may have occurred in or continued well into the Lower Palaeozoic, as suggested by (1) Early-Middle Ordovician fossils locally found associated with detrital serpentinites, (2) the presence of clastic zircons of Early and Middle Ordovician age and (3) the minor Late Cambrian to Middle Ordovician intrusive rocks intruding the transitional crust basin (see above and overview in Jakob et al. [44]).

In the SNC, however, ductile extensional shear zones in the allochthonous Baltican crystalline basement at the base of the SNC near Sarek formed as early as $\sim 637 \mathrm{Ma}(\mathrm{U} / \mathrm{Pb}$ on titanite [103]). This was succeeded by partial melting of the syn-rift sediments at $\sim 610 \mathrm{Ma}$ (U/Pb on zircon). This deformation also included low-angle and layer-parallel extensional faults and shear zones in the syn-rift sediments, subsequently truncated by the $\sim 603$ Ma SDC-LIP [20,26-28]. These radiometric ages and field observations document that pre-break-up extension and regional heating commenced immediately prior to the emplacement of the dykes of the SDC-LIP. A long-lasting extension and crustal thinning are also in agreement with the pre-break-up formation of the proximal continental rift basins of Cryogenian to Ediacaran age ('sparagmite basins') in Scandinavia [2].

The most distal part of the Baltican rifted margin, outboard the JMC, was affected by Pre-Scandian plate convergence, which may have commenced in the Early Ordovician ( 480 Ma) and culminated in the Middle Ordovician ( 450 Ma) [59,86,89]. Radiometric dating of (U)HP assemblages in the Seve and JMC are Early Ordovician to Earliest Silurian (480 to $450 \mathrm{Ma}$ and $436 \mathrm{Ma}$ ), respectively, and demonstrate deep burial of distal margin segments during the Early Caledonian stages of the orogeny and during the initial collision and nappe formation. Outboard the JMC, the Ordovician metamorphic rocks of the Dalsfjord-Høyvik basement cover pair of the JMC were buried and exhumed to the surface prior to deposition of the fossiliferous Middle Silurian Herland Group. Obduction of the Solund-Stavfjord Ophiolite (443 $\pm 3 \mathrm{Ma})$ onto the distal margin of the JMC, as seen in the Atløy area (Figure 1), was contemporaneous with deposition of the upper parts of the Herland Gp. stratigraphy [82,89]. There is, however, apparently no stratigraphic evidence of a similar Pre-Scandian exhumation of the distal Baltican margin exposed in the SNC prior to the Scandian collision.

The Pre-Scandian rifted-margin geometry, which produced the JMC promontory and its inboard mantle-floored basin from the Late Neoproterozoic (?) into the Ordovician, was a major along- and across-strike irregularity of the Pre-Caledonian margin of Baltica. This rift-inherited geometry exerted a strong control on the subsequent orogenic structural geometry. It also controlled the diachronous sequence of events both along and acrossstrike during the Scandian Orogeny. For example, the rift inheritance gave rise to both the diachronous burial (Early Caledonian to Scandian) and exhumation histories along- and across-strike from distal to proximal parts of the mountain belt.

It is likely that the seaway inboard the JMC, floored by transitional crust, remained little-affected by Caledonian deformation and metamorphism until initiation of the Scandian shortening in the Early to Middle Silurian ( 438 to $430 \mathrm{Ma}$; $[44,60])$. The Scandian continental collision commenced after the final closure of the Iapetus and the Wenlock (433-27 Ma) obduction of the Solund-Stavfjord Ophiolite onto the Herland Gp. sediments and the JMC. Stratigraphic evidence of the build-up of an orogenic wedge also includes the latest Ordovician to Silurian clastic wedges, apparently with a westerly source deposited onto the Baltican foreland [118]. After the Middle Silurian, the continuous convergence, resulting in the Scandian continental collision, affected all rocks in the mountain belt. 
The application of the hyperextension model to explain the large number of metaperidotites associated with the continental basement and paragneisses of the Western Gneiss Region (Figure 1) has not been addressed in the present study, and cannot yet be substantiated due to the lack of dedicated studies to explore this possibility. This model may be difficult to argue with certainty also in the future due to the intensity of the Scandian and the strong post-orogenic structural and metamorphic overprint during the subduction and eduction of these rocks $[43,78]$. Most published models suggest that emplacement of the (U)HP eclogites and metaperidotites in the WGR was related to subduction and post-orogenic eduction/extension [43]. Detailed studies of the PT time histories of these metaperidotites and their intimate association with continental crust and paragneisses are indeed complex and have been taken to indicate several stages of (U)HP metamorphism $[119,120]$ and are not discussed further here.

The results of the project as discussed and summarized here demonstrate that the Scandian deformation and metamorphism postdate pre-orogenic exhumation and metasomatism commonly found in the metaperidotites and their detrital derivatives of the metaperidotite-bearing unit. Jakob et al. [64] have demonstrated that in all localities where stable isotopes were analyzed in the metaperidotite-bearing unit, the $\delta^{18} \mathrm{O}$ and $\delta^{13} \mathrm{C}$ values of fossil shell fragments as well as ophicarbonate veins were reset by the Scandian metamorphism. Early Caledonian ( 480-460 Ma) orogenic overprint also postdates the contact metamorphic and contact metasomatic scapolitization of the SDC dolerites of the SNC. Inboard the JMC, effects of the Early Caledonian orogenic events are not documented; instead, exhumation of metaperidotites to the surface and deposition of their detrital equivalents apparently took place at this time. The rocks of this mantle-floored transitional crust basin are therefore either younger or were shielded from the Early Caledonian events and only experienced the main Scandian orogeny, whereas the most distal margin as well as the Iapetus margin of the JMC underwent Pre-Scandian contractional event(s).

This observation demonstrates the diachronous evolution from the hinterland outboard the JMC across the transitional crust basin with metaperidotites to the foreland. Presently, we are not aware of any direct stratigraphic or radiometric evidence to precisely constrain the age of the mantle exhumation in the metaperidotite-bearing unit inboard the JMC. Correlation of these units with those at Otta and at Sjong near Lesja, however, suggest that mantle was exposed at the seafloor in the latest Cambrian to Middle Ordovician. A minimum age for the opening of this basin, which separated JMC from mainland Baltica, is provided by a Late Cambrian ( $487 \pm 1 \mathrm{Ma}$ ) pegmatitic gabbro with dolerites at Samnanger near Bergen [44]. A minor and intensely deformed granite pegmatite (now an augen gneiss) and a small diorite also intruded these units at $476 \pm 2$ and $471 \pm 2 \mathrm{Ma}$, in Samnanger and Stølsheimen (Figure 1), respectively [44]. This suggests that the Baltica margin experienced extension and a high geotherm into the latest Cambrian to lower Middle Ordovician [44]. The youngest dated clastic zircons ( 467 Ma) [121] in the transitional crust basin inboard the JMC show that sedimentation in this in-part mantle-floored basin continued at least into the Middle Ordovician.

The youngest intrusive rocks in this basin are partial-melt granites intruded at $421 \pm 2 \mathrm{Ma}$, and coincide with the main Scandian collision [44]. These are near coeval with partial-melt granite dykes ( $\sim 25 \mathrm{Ma}$ and $427 \pm 1 \mathrm{Ma})$ intruding the distal parts of the overlying JMC $[122,123]$. It is also likely, but remains to be demonstrated, that sedimentation in the transitional crust, mantle-floored basin inboard the JMC may have continued until the onset of the Scandian orogeny that affected all rocks in the mountain belt. Regional metamorphism of the mantle-floored basin inboard the JMC is dated at $438 \pm 6$ to $427 \pm 2 \mathrm{Ma}$ (titanite and metamorphic zircon) [44]. These ages partly overlap with the early eclogite ( $\sim 29 \pm 4 \mathrm{Ma}, \mathrm{U}-\mathrm{Pb}$ zircon age) to later amphibolite (423 $\pm 1 \mathrm{Ma})$ facies metamorphism in the Lindås nappe of the JMC and with the Middle Silurian (Wenlock) obduction of the Solund Stavfjord Ophiolite Complex onto the JMC in western Norway $[60,83,89,90]$. The Neoproterozoic magma-rich margin along the future SNC and outboard the JMC were affected by polyphase Caledonian deformation and metamorphic overprint (see above), 
but this early tectonic history and its structural relationship to the Scandian collision are not yet sufficiently documented along the length of the orogen.

In view of the previous and recent work outlined here, we argue that exhumation by Pre-Scandian hyperextension offers a better explanation than previous models, appealing to collision and dismembered ophiolites, to explain the sediment-hosted solitary and associated detrital metaperidotites in the Scandinavian Caledonides. We have shown that the exhumation and metasomatic alteration of these mantle lithologies took place prior to formation of all the Scandian deformation fabrics and their metamorphic overprint. The exhumed mantle lithologies are also associated with sheets of Baltican crystalline basement and are sandwiched between units commonly interpreted to be of Baltican origin (JMC and $\mathrm{SNC}$ ). The Neoproterozoic syn-rift sediments along the Pre-Caledonian margin of Baltica also include meta-evaporites in the SNC [97]. The abundant LIP-related mafic dykes and minor preserved volcanics associated with the SDC were emplaced along the distal Iapetus margin of Baltica, outboard the JMC. We support previous interpretations, e.g., [98,124], that this represented the Neoproterozoic magma-rich ocean-continent transition zone between Baltica and the Iapetus Ocean.

Regionally along the entire mountain belt, the Alpine-type solitary metaperidotitebearing complexes and the JMC nappes are structurally overlain by the Cambrian to Early Silurian Penrose-type ophiolites and associated island arc complexes. Some of these Early Ordovician complexes have Laurentian fossils and clastic zircon populations that indicate that they were formed closer to Laurentia than Baltica [125]. The outboard oceanic unit(s) display a polyphase Pre-Scandian history [46] and contain a number of Silurian ( 440-430 Ma) arc-related gabbroic to granitic plutons emplaced up to $1350 \mathrm{~km}$ (Magerøy) outboard their present position in the Caledonides $[50,92,126]$. This suggests they were formed in the hanging wall/upper plate in one (or more) of the intra-Iapetus subduction zones, with subduction polarity away from the Baltican margin [50].

Mafic dykes and the mantle-derived metaperidotites and their country rocks of the Neoproterozoic sediments in the SNC underwent intermediate to HP and locally UHP metamorphism prior to the Scandian orogeny $[85,115]$. The mechanism by which these metaperidotites were emplaced into the Neoproterozoic SNC sediments is poorly understood. It is unlikely they were exhumed by hyperextension during rifting, as there is no evidence of detrital peridotites in the lower SNC. Similarly, their exhumation history and juxtaposition with the overlying lower grade (Køli NC), where detrital metaperidotites do occur during the orogeny, is poorly understood.

\section{Conclusions}

We conclude that the more than $2000 \mathrm{~km}$ long (North Sea to Barents Sea, present geographic reference) and up to $1500 \mathrm{~km}$ wide Pre-Scandian, Pre-Caledonian margin of Baltica constituted a highly complex margin architecture after completion of the rifting and Iapetus break-up in the Late Neoproterozoic and into the Middle Ordovician. The break-up at approximately $600 \mathrm{Ma}$ was related to arrival of the large-scale mantle plume, the Central Iapetus Magmatic Province (CIMP), and its expression in Scandinavia was the SDC ( $\sim 603 \mathrm{Ma})$ and its late-stage magmatic rocks ( $\sim 580$ to $525 \mathrm{Ma})$. Neoproterozoic proximal parts of the margin, inboard the necking zone, were characterized by continental rift basins with only very local rift magmatism [2]. Inboard the JMC, a transitional crust basin was hyperextended, exhuming subcontinental mantle accompanied by local magmatism into the Ordovician [44]. This segment, inboard the JMC, also included extensional allochthons of Baltican basement slivers. There is, however, no available stratigraphic evidence that the metaperidotites of the transitional hyperextended crust were exhumed to the seafloor until the Early Ordovician. Outboard the JMC, the margin was magma-rich and the $>900 \mathrm{~km}$ long exposed segment of the magma-rich margin is remarkably well-preserved in the Särv and SNCs and at Roukonborri and Corrovarre in the northernmost Caledonides, and locally also in the outboard margin of the JMC at Atløy (Figures 1 and 5). 
Both the margin's width and its along-strike architecture were highly variable, with the JMC promontory and inboard transitional crust basin as a major difference from south to north. The JMC together with the Neoproterozoic magma-poor-to-rich transition later controlled the Caledonian orogenic evolution, particularly the development (or not) of Pre-Scandian collisional events, as well as the diachroneity of the Scandian orogeny itself.

Here, we have emphasized the importance of the pre-collision rift inheritance to explain the present architecture of the Scandinavian Caledonides. We have also argued that the pre-orogenic architecture of the margin may have been strongly influenced by inheritance from the Proterozoic structure in the Baltican basin, most notably the Sveconorwegian front in southern Norway and Sweden. An important final statement is that this very large Himalayan-type mountain belt cannot be understood in detail unless the pre-collision structural template is better known, and that further detailed field investigations are necessary to improve this understanding. The studies presented and reviewed here have been directed to take steps in this direction, and new concepts related to modern margin studies have been introduced and used for the Scandinavian Caledonides. However, as also shown above, several remaining issues should be addressed in future studies.

Author Contributions: T.B.A., J.J., H.J.K. and C.T. all contributed to field work, analytical efforts and the project work that is summarized in the interpretations and conclusions presented here. The paper is written by T.B.A. All authors, and in particular J.J. have contributed with suggestions and revisions to the final version. All authors have read and agreed to the published version of the manuscript.

Funding: This research was funded by the Research Council of Norway (Norges Forskningsråd (NFR), Fri-Nat Project 250327): Hyperextension in magma-poor and magma-rich domains along the Pre-Caledonian Margin of Baltica and Research Council of Norway through its Centers of Excellence funding scheme, project number 223272.

Acknowledgments: An early version of this manuscript benefitted from detailed comments and suggestions from Haakon Fossen, Cees van Staal and Trond H. Torsvik. Two anonymous reviewers helped to improve the final version of the manuscript.

Conflicts of Interest: The authors declare no conflict of interest.

\section{References}

1. Peron-Pinvidic, G.; Manatschal, G.; Alves, T.; Andersen, T.B.; Andres-Martiniz, M.; Autin, J.; Ball, P.; Brune, S.; Cadenas, P.; Cresswell, D.; et al. "IMAGinING RIFTING" Workshop Participants. Rifted Margins: State of the Art and Future Challenges. Front. Earth Sci. 2019, 7. [CrossRef]

2. Nystuen, J.P.; Andresen, A.; Kumpulainen, R.A.; Siedlecka, A. Neoproterozoic Basin Evolution in Fennoscandia, East Greenland and Svalbard. Episodes 2008, 31, 35-43. [CrossRef] [PubMed]

3. Jakob, J.; Andersen, T.B.; Kjøll, H.J. A Review and Reinterpretation of the Architecture of the South and South-Central Scandinavian Caledonides-A Magma-Poor to Magma-Rich Transition and the Significance of the Reactivation of Rift Inherited Structures. Earth-Sci. Rev. 2019, 192, 513-528. [CrossRef]

4. Boillot, G.; Grimaud, S.; Mauffret, A.; Mougenot, D.; Kornprobst, J.; Mergoil-Daniel, J.; Torrent, G. Ocean-Continent Boundary off the Iberian margin: A Serpentinite Diapir West of the Galicia Bank. EPSL 1980, 48, 23-34. [CrossRef]

5. Boillot, G.; Recq, M.; Winterer, E.L.; Meyer, A.W.; Applegate, J.; Baltuck, M.; Bergen, J.A.; Comas, M.C.; Davies, T.A.; Dunham, K.; et al. Tectonic Denudation of the Upper Mantle along Passive Margins: A Model Based on Drilling Results (ODP Leg 103, Western Galicia Margin, Spain). Tectonophysics 1987, 132, 335-342. [CrossRef]

6. Boillot, G.; Froitzheim, N. Non-Volcanic Rifted Margins, Continental Break-up and the Onset of Sea-Floor Spreading: Some Outstanding Questions. Geol. Soc. Lond. Spec. Publ. 2001, 187, 9-30. Available online: https://sp.lyellcollection.org/content/187/ $1 / 9$ (accessed on 28 November 2021). [CrossRef]

7. Peron-Pinvidic, G.; Manatschal, G.; Osmundsen, P.T. Structural Comparison of Archetypal Atlantic Rifted Margins: A Review of Observations and Concepts. Mar. Pet. Geol. 2013, 43, 21-47. [CrossRef]

8. Abdelmalak, M.M.; Andersen, T.B.; Planke, S.; Faleide, J.I.; Corfu, F.; Tegner, C.; Shephard, G.E.; Zastrozhnov, D.; Myklebust, R. The Ocean-Continent Transition in the Mid-Norwegian Margin: Insight from Seismic Data and an Onshore Caledonian Field Analogue. Geology 2015, 43, 1011-1014. [CrossRef]

9. Osmundsen, P.T.; Peron-Pinvidic, G.; Ebbing, J.; Erratt, D.; Fjellanger, E.; Bergslien, D.; Syvertsen, S.E. Extension, Hyperextension and Mantle Exhumation Offshore Norway: A Discussion Based on 6 Crustal Transects. Nor. J. Geol. 2016, 96, 343-372. [CrossRef]

10. Manatschal, G. New Models for Evolution of Magma-Poor Rifted Margins Based on a Review of Data and Concepts from West Iberia and the Alps. Int. J. Earth Sci. 2004, 93, 432-466. [CrossRef] 
11. Epin, M.E.; Manatschal, G.; Amann, M. Defining Diagnostic Criteria to Describe the Role of Rift Inheritance in Collisional Orogens: The Case of the Err-Platta Nappes. Swiss J. Geosci. 2017, 110, 1-20. [CrossRef]

12. Lagabrielle, Y.; Labaume, P.; de Saint Blanquat, M. Mantle Exhumation, Crustal Denudation, and Gravity Tectonics during Cretaceous Rifting in the Pyrenean Realm (SW Europe): Insights from the Geological Setting of the Lherzolite Bodies. Tectonics 2010, 29, 1-26. [CrossRef]

13. Clerc, C.; Lagabrielle, Y.; Neumaier, M.; Reynaud, J.Y.; de Saint Blanquat, M. Exhumation of Subcontinental Mantle Rocks: Evidence from Ultramafic-Bearing Clastic Deposits nearby the Lherz Peridotite Body, French Pyrenees. Bull. Soc. Géol. France 2012, 183, 443-459. [CrossRef]

14. Beltrando, M.; Manatschal, G.; Mohn, G.; Dal Piaz, G.V.; Vitale Brovarone, A.; Masini, E. Recognizing Remnants of Magma-Poor Rifted Margins in High-Pressure Orogenic Belts: The Alpine Case Study. Earth-Sci. Rev. 2014, 131, 88-115. [CrossRef]

15. Andersen, T.B.; Labrousse, L.; Corfu, F.; Osmundsen, P.T. Evidence for Hyperextension along the Pre-Caledonian Margin of Baltica. J. Geol. Soc. Lond. 2012, 169, 601-612. [CrossRef]

16. van Staal, C.R.; Chew, D.M.; Zagorevski, A.; McNicoll, C.; Hibbard, J.; Sébastien, C.; Escayola, M.P.; Sylvester, P.J. Evidence of Late Ediacaran Hyperextension of the Laurentian Iapetan Margin in the Birchy Complex, Baie Verte Peninsula, North-West Newfoundland: Implications for the Opening of Iapetus, Formation of Peri-Laurentian Microcontinents and Taconic-Grampian Orogenesis. Geosci. Can. 2013, 40, 94-117. [CrossRef]

17. Chew, D.M.; van Staal, C.R. The Ocean-Continent Transition Zones along the Appalachian-Caledonian Margin of Laurentia: Examples of Large-Scale Hyperextension during the Opening of the Iapetus Ocean. Geosci. Can. 2014, 41-42, 165-185. [CrossRef]

18. Franke, D. (Rifting, Lithosphere Breakup and Volcanism: Comparison of Magma-Poor and Volcanic Rifted Margins. Mar. Pet. Geol. 2013, 43, 63-87. Available online: https:/ / www.sciencedirect.com/science/article/abs/pii/S0264817212002322 (accessed on 28 November 2021). [CrossRef]

19. Dewey, J.F.; Burke, K. Hot Spots and Continental Break-up: Implications for Collisional Orogeny. Geology 1974, 2, 57-60. [CrossRef]

20. Gee, D.G.; Andréasson, P.-G.; Li, Y.; Krill, A. Baltoscandian Margin, Sveconorwegian Crust Lost by Subduction during Caledonian Collisional Orogeny. GFF 2016, 139, 36-51. [CrossRef]

21. Talbot, C.J.; Ghebreab, W. Red Sea Detachment and Basement Core Complexes in Eritrea. Geology 1997, 25, 655-658. [CrossRef]

22. Bastow, I.D.; Keir, D. The Protracted Development of the Continent-Ocean Transition in Afar. Nat. Geosci. 2011, 4, 248. [CrossRef]

23. Klausen, M.B.; Larsen, H.C. East Greenland Coast-Parallel Dike Swarm and Its Role in Continental Breakup. Spec. Paper Geol. Soc. Am. 2002, 362, 133-158. [CrossRef]

24. Geoffroy, L. Volcanic Passive Margins. Comptes Rendus Geosci. 2005, 337, 1395-1408. [CrossRef]

25. Svenningsen, O.M. The Baltica-Lapetus Passive Margin Dyke Complex in the Sarektjokka Nappe, Northern Swedish Caledonides. Geol. J. 1994, 29, 323-354. [CrossRef]

26. Andréasson, P.-G.; Allen, A.; Aurell, O.; Boman, D.; Ekestubbe, J.; Goerke, U.; Lundgren, A.; Nilsson, P.; Sandelin, S. Seve Terranes of the Kebnekaise Mts., Swedish Caledonides, and Their Amalgamation, Accretion and Affinity. GFF 2018, 140, 1-28. [CrossRef]

27. Kjøll, H.J.; Andersen, T.B.; Corfu, F.; Labrousse, L.; Tegner, C.; Abdelmalak, M.M.; Planke, S. Timing of Break-up and Thermal Evolution of a Pre-Caledonian Neoproterozoic Exhumed Magma-Rich Rifted Margin. Tectonics 2019, 38, 1843-1862. [CrossRef]

28. Kjøll, H.J.; Galland, O.; Labrousse, L.; Andersen, T.B. Emplacement Mechanisms of a Dyke Swarm across the Brittle-Ductile Transition and the Geodynamic Implications for Magma-Rich Margins. Earth Planet. Sci. Lett. 2019, 518, 223-235. [CrossRef]

29. Tegner, C.; Andersen, T.B.; Kjøll, H.J.; Brown, E.L.; Hagen-Peter, G.; Corfu, F.; Planke, S.; Torsvik, T.H. A Mantle Plume Origin for the Scandinavian Dyke Complex: A Piercing Point for the 615 Ma Plate Reconstruction of Baltica. Geochem. Geophys. Geosyst. 2019, 20, 1075-1094. [CrossRef]

30. White, R.S.; Smith, L.K.; Roberts, A.W.; Christie, P.A.F.; Kusznir, N.J. The iSIMM Team. Lower-Crustal Intrusion on the North Atlantic Continental Margin. Nature 2008, 452, 460-464. [CrossRef]

31. French, S.W.; Romanowicz, B. Broad Plumes Rooted at the Base of the Earth's Mantle beneath Major Hotspots. Nature 2015, 525, 95-99. Available online: https:/ / www.nature.com/articles/nature14876 (accessed on 28 November 2021). [CrossRef] [PubMed]

32. Dubrovine, P.V.; Steinberger, B.; Torsvik, T.H. A Failure to Reject: Testing the Correlation between Large Igneous Provinces and Deep Mantle Structures with EDF Statistics. Geochemistry 2016, 17, 1130-1163. [CrossRef]

33. Molnar, P. Lower Mantle Dynamics Perceived with 50 Years of Hindsight from Plate Tectonics. Geochem. Geophys. Geosyst. 2019, 20,5619-5649. [CrossRef]

34. Torsvik, T.H.; Van der Voo, R.; Doubrovine, P.V.; Burke, K.; Steinberger, B.; Ashwal, L.D.; Trønnes, R.; Webb, S.J.; Bull, A.L. Deep Mantle Structure as Reference Frame for Movements in and on the Earth. Proc. Nat. Acad. Sci. USA 2014, 111-124, 8735-8740. Available online: https://www.pnas.org/content/111/24/8735 (accessed on 28 November 2021). [CrossRef] [PubMed]

35. Domeier, M. A Plate Tectonic Scenario for the Iapetus and Rheic Oceans. Gondwana Res. 2016, 36, 275-295. [CrossRef]

36. Ernst, R.E.; Bell, K. Large Igneous Provinces (LIPs) and Carbonatites. Min. Petrol. 2010, 98, 55-76. [CrossRef]

37. Bingen, B.; Demaiffe, D.; Breemen, O.V. The 616 Ma Old Egersund Basaltic Dike Swarm, SW Norway, and Late Neoproterozoic Opening of the Iapetus Ocean. J. Geol. 1998, 106, 565-574. [CrossRef]

38. Walderhaug, H.J.; Torsvik, T.H.; Halvorsen, E. The Egersund Dykes (SW Norway): A reliable Early Ediacaran (Vendian) Palaeomagnetic Pole from Baltica. Geophys. J. Intern. 2007, 168, 935-948. [CrossRef]

39. Meert, J.G.; Torsvik, T.H.; Eide, E.A.; Dahlgren, S. Tectonic Significance of the Fen Province, S. Norway. Constraints from Geochronology and Palaeomagnetism. J. Geol. 1998, 106, 553-564. [CrossRef] 
40. Roberts, R.J.; Corfu, F.; Torsvik, T.H.; Ashwal, L.D.; Ramsay, D.M. Short-Lived Mafic Magmatism at 560-570 Ma in the Norwegian Caledonites: U-Pb Zircon Ages from the Seiland Igneous Province. Geol. Mag. 2006, 143, 887-903. [CrossRef]

41. Roberts, R.J.; Corfu, F.; Torsvik, T.H.; Hetherington, C.J.; Ashwal, L.D. Age of Alkaline Rocks in the Seiland Igneous Province, Northern Norway. J. Geol. Soc. Lond. 2010, 167, 71-81. Available online: https://jgs-lyellcollection-org.ezproxy.uio.no/content/ 167/1/71 (accessed on 28 November 2021). [CrossRef]

42. Larsen, R.B.; Grant, T.; Sørensen, B.E.; Tegner, C.; McEnroe, S.; Pastore, Z.; Fichler, C.; Nikolaisen, E.; Grannes, K.R.; Church, N.; et al. Portrait of a Giant Deep-Seated Magmatic Conduit System: The Seiland Igneous Province. Lithos 2018, 296-299, 600-622. [CrossRef]

43. Andersen, T.B.; Jamtveit, B.; Dewey, J.F.; Swensson, E. Subduction and Eduction of Continental Crust; Major Mechanisms during Continent-Continent Collision and Orogenic Extensional Collapse. Terra Nova 1991, 3, 303-310. [CrossRef]

44. Jakob, J.; Alsaif, M.; Corfu, F.; Andersen, T.B. Age and Origin of Thin Discontinuous Gneiss Sheets in the Distal Domain of the Magma-Poor Hyperextended Pre-Caledonian Margin of Baltica, Southern Norway. J. Geol. Soc. Lond. 2017, 174, 557-571. Available online: https://jgs-lyellcollection-org.ezproxy.uio.no/content/174/3/557 (accessed on 28 November 2021). [CrossRef]

45. Furnes, H.; Ryan, P.D.; Grenne, T.; Roberts, D.; Sturt, B.A.; Prestvik, T. Geological Land Geochemical Classification of the Ophiolite Fragments in the Scandinavian Caledonides. In The Caledonide Orogen-Scandinavia and Related Areas; Gee, D.G., Sturt, B.A., Eds.; Wiley: New York, NY, USA, 1985; pp. 657-670.

46. Andersen, T.B.; Andresen, A. Stratigraphy, Tectonostratigraphy and Accretion of Outboard Terranes in the Caledonides of Sunnhordland W. Norway. Tectonophys 1994, 231, 71-84. [CrossRef]

47. Slagstad, T.; Pin, C.; Roberts, D.; Kirkland, C.L.; Grenne, T.; Dunning, G.; Sauer, S.; Andersen, T. Tectonomagmatic Evolution of the Early Ordovician Suprasubduction-Zone Ophiolites of the Trondheim Region, Mid-Norwegian Caledonides. Spec. Publ. Geol. Soc. Lond. 2014, 390, 541-561. Available online: https://sp-lyellcollection-org.ezproxy.uio.no/content/390/1/541 (accessed on 28 November 2021). [CrossRef]

48. Bruton, D.L.; Harper, D.A.T. Brachiopods and Trilobites of the Early Ordovician Serpentine Otta Conglomerate, South Central Norway. Nor. J. Geol. 1981, 61, 153-181. Available online: http://www.geologi.no/images/NJG_articles/NGT_61_2_153-181.pdf (accessed on 28 November 2021).

49. Torsvik, T.H.; Cocks, R. Earth History and Palaeogeography; University Press Cambridge: Cambridge, UK, 2017; p. 291. Available online: https:/ / www.cambridge.org/core/books/abs/earth-history-and-palaeogeography/earth-history-and-palaeogeography/ 09D7FE97DD2EDBF59F857B8CC697C6E3 (accessed on 29 November 2021).

50. Slagstad, T.; Kirkland, C.L. Timing of Collision Initiation and Location of the Scandian Orogenic Suture in the Scandinavian Caledonides. Terra Nova 2018, 30, 179-188. [CrossRef]

51. Roberts, D.; Gee, D.G. An Introduction to the Structure of the Scandinavian Caledonides. In The Caledonide Orogen-Scandinavia and Related Areas; Gee, D.G., Sturt, B.A., Eds.; Wiley: New York, NY, USA, 1985; pp. 55-68.

52. Stephens, M.B.; Gee, D.G. Terranes and Polyphase Accretionary History in the Scandinavian Caledonides. Geol. Soc. Am. Spec. Paper 1989, 230, 17-30. [CrossRef]

53. Corfu, F.; Andersen, T.B.; Gasser, D. The Scandinavian Caledonides: Main Features, Conceptual Advances and Critical Questions Spec. Publ. Geol. Soc. Lond. 2014, 390, 9-43. [CrossRef]

54. Froitzheim, N.; Eberli, G.P. Extensional Detachment Faulting in the Evolution of a Tethys Passive Continental Margin, Eastern Alps, Switzerland. Geol. Soc. Am. Bull. 1990, 102, 1297-1308. [CrossRef]

55. Faerseth, R.B.; Thon, A.; Larsen, S.G.; SIivertsen, A.; Elvestad, L. Geology of the Lower Palaeozoic Rocks in the SamnangerOsterøy, Area, Major Bergen Arc, Western Norway. Bull. Nor. Geol. Unders. 1977, 334, 19-58.

56. Roberts, D. The Scandinavian Caledonides: Event Chronology, Paleogeographic Settings and Likely, Modern Analogues. Tectonophys 2003, 365, 283-299. [CrossRef]

57. Nilsson, L.-P.; Roberts, D. A Trail of Ophiolitic Debris and Its Detritus along the Trøndelag-Jämtland Border: Correlations and Palaeogeographical Implications. Bull. Nor. Geo. Unders. 2014, 453, 29-41. Available online: https://www.ngu.no/upload/ Publikasjoner/Bulletin/Bulletin453_29-41.pdf (accessed on 28 November 2021).

58. Andersen, T.B.; Berry, H.N.; Lux, D.R.; Andresen, A. The Tectonic Significance of Pre-Scandian 40Ar/39Ar Phengite Cooling Ages the Caledonides of Western Norway. J. Geol. Soc. Lond. 1998, 155, 297-309. Available online: https://jgs-lyellcollection-org. ezproxy.uio.no/content/155/2/297 (accessed on 28 November 2021). [CrossRef]

59. Root, D.; Corfu, F. U-Pb Geochronology of Two Discrete Ordovician High-Pressure Metamorphic Events in the Seve Nappe Complex, Scandinavian Caledonides. Contrib. Min. Petrol. 2012, 163, 769-788. [CrossRef]

60. Glodny, J.; Kühn, A.; Austrheim, H. Geochronology of Fluid-Induced Eclogite and Amphibolite Facies Metamorphic Reactions in a Subduction-Collision System, Bergen Arcs, Norway. Contrib. Min. Petrol. 2008, 156, 27-48. [CrossRef]

61. Stigh, J. Ultramafites and Detrital Serpentinites in the Central and Southern Parts of the Caledonian Allochthon in Scandinavia. Ph.D. Thesis, University of Gothenburg, Gothenburg, Sweden, 1979; 222p.

62. Qvale, H.; Stigh, J. Ultramafic Rocks in the Scandinavian Caledonides. In The Caledonide Orogen-Scandinavia and Related Areas, Gee, D.G., Sturt, B.A., Eds.; Wiley: New York, NY, USA, 1985; pp. 693-715.

63. Enger, A.S. Solitary Mantle Peridotite Bodies in Stølsheimen, Central South Norway. Master's Thesis, University of Oslo, Oslo, Norway, 2016; 147p. Available online: https:/ / www.duo.uio.no/handle/10852/50179 (accessed on 28 November 2021). 
64. Jakob, J.; Boulvais, P.; Andersen, T.B. Oxygen and Carbon Isotope Composition from a Regional Melange Basin in the South Norwegian Caledonides: Origin and Resetting. Intern. J. Earth Sci. 1917, 107, 1445-1463. [CrossRef]

65. Dunkel, K.G.; Jamtveit, B.; Austrheim, H. Ophicarbonates of the Feragen Ultramafic Body, Central Norway. Nor. J. Geol. 2019, 99, 3. [CrossRef]

66. Dilek, Y.; Furnes, H. Ophiolites and Their Origins. Elements 2014, 10, 93-100. Available online: https:/ / pubs.geoscienceworld. org/msa/elements/article-abstract/10/2/93/137595/Ophiolites-and-Their-Origins (accessed on 28 November 2021). [CrossRef]

67. Harper, D.A.T.; Bruton, D.L.; Rasmussen, C.M.Ø. The Otta Brachiopod and Trilobite Fauna: Palaeogeography of Early Palaeozoic Terranes and Biotas across Baltoscandia. Foss. Strata 2008, 54, 31-40.

68. Bonatti, E.; Hamlyn, P.R.; Ottonello, G. Upper Mantle beneath a Young Oceanic Rift: Peridotites from the Island of Zabargad (Red Sea). Geology 1981, 9, 474-479. Available online: https: / / pubs.geoscienceworld.org/gsa/geology/article/9/10/474/195751/ Upper-mantle-beneath-a-young-oceanic-rift (accessed on 28 November 2021). [CrossRef]

69. Beinlich, A.; Austrheim, H.; Glodny, J.; Erambert, M.; Andersen, T.B. $\mathrm{CO}_{2}$ Sequestration and Extreme Mg Depletion in Serpentinised Peridotite Clasts from the Devonian Solund Basin, SW-Norway. Geochim. Cosmochim. Acta 2010, 74, 6935-6964. [CrossRef]

70. Bergman, S. A Possible Ophiolite at Handöl, Swedish Caledonides. GFF 1987, 109, 340-343. [CrossRef]

71. Bergman, S. P-T Paths in the Handöl Area, Central Scandinavia: Record of Caledonian Accretion of Outboard Rocks to the Baltoscandian Margin. J. Metam. Geol. 1992, 10, 265-281. [CrossRef]

72. Beinlich, A.; Plümper, O.; Hövelmann, J.; Austrheim, H.; Jamtveit, B. Massive Serpentinite Carbonation at Linnajavri, N-Norway. Terra Nova 2012, 24, 446-455. [CrossRef]

73. Beinlich, A.; Austrheim, H.; Mavromatis, V.; Grguric, B.; Putnis, C.V.; Putnis, A. Peridotite Weathering Is the Missing Ingredient of Earth's Continental Crust Composition. Nat. Comm. 2018, 9, 1-12. [CrossRef]

74. Fauconnier, J.; Labrousse, L.; Andersen, T.B.; Beyssac, O.; Duprat-Oualid, S.; Yamato, P. Thermal Structure of a Major Crustal Shear Zone, the Basal Thrust in the Scandinavian Caledonides. Earth Planet. Sci. Lett. 2014, 385, 162-171. [CrossRef]

75. Kjelberg, Ø. Petrography, Structure and Metamorphism of Mélange Rocks below the Jotun Nappe in Stølsheimen, Central South Norway. Master's Thesis, University of Oslo, Oslo, Norway, 2015; 114p. Available online: https://www.duo.uio.no/handle/1085 2/49682 (accessed on 28 November 2021).

76. Quintela, O. Structural Geology and Tectonic History of a Caledonian Metaperidotite-Bearing Metasedimentary Complex near Lesja, South Central Norway. Master's Thesis, University of Oslo, Oslo, Norway, 2019; 141p. Available online: https:/ / www.duo.uio.no/handle/10852/70023 (accessed on 28 November 2021).

77. Bakke, S.; Korneliussen, A. Jack-Straw-Textured Olivines in some Norwegian Metaperidotites. Nor. J. Geol. 1986, 66, 271-276. Available online: http://www.geologi.no/images/NJG_articles/NGT_66_4_271-276.pdf (accessed on 28 November 2021).

78. Hacker, B.R.; Andersen, T.B.; Johnston, S.; Kylander-Clark, A.R.; Peterman, E.M.; Walsh, E.O.; Young, D. High-Temperature Deformation during Continental-Margin Subduction \& Exhumation: The Ultrahigh-Pressure Western Gneiss Region of Norway. Tectonophysics 2010, 480, 149-171. [CrossRef]

79. Corfu, F.; Heim, M. Geochronology of Caledonian Metamorphic Allochthons in the Otta-Heidal Region, South Norway; Tectonostratigraphic and Palaeogeographic Implications. J. Geol. Soc. Lond. 2019, 177, 66-81. Available online: https://jgslyellcollection-org.ezproxy.uio.no/content/177/1/66 (accessed on 28 November 2021). [CrossRef]

80. Corfu, F.; Andersen, T.B. Proterozoic Magmatisms in the Southern Scandinavian Caledonides with Special Reference to the Occurrences in the Eikefjord Nappe. GFF 2016, 138, 102-114. [CrossRef]

81. Austrheim, H. Eclogitization of Lower Crustal Granulites by Fluid Migration through Shear Zones. EPSL 1987, 81, 221-232. [CrossRef]

82. Brekke, H.; Solberg, P.O. The Geology of Atløy, Sunnfjord Western Norway. Bull. Nor. Geol. Unders. 1987, 410, 73-94.

83. Jamtveit, B.; Moulas, E.; Andersen, T.B.; Austrheim, H.; Corfu, F.; Petley-Ragan, A.; Schmalholz, S. High-Pressure Metamorphism Caused by Fluid Induced Weakening of Deep Continental Crust. Sci. Rep. 2018, 8, 1-8. [CrossRef]

84. Andréasson, P.-G.; Albrecht, L.G. Derivation of 500 Ma Eclogites from the Passive Margin of Baltica and a Note on the Tectonometamorphic Heterogeneity of Eclogite-Bearing Crust. Geol. Mag. 1995, 132, 729-773. [CrossRef]

85. Brueckner, H.K.; van Roermund, H.L.M. Dunk Tectonics: A Multiple Subduction/Eduction Model for the Evolution of the Scandinavian Caledonides. Tectonics 2004, 23. [CrossRef]

86. Klonowska, I.; Janak, M.; Majka, J.; Froitzheim, N.; Kosminska, K. Eclogite and Garnet Pyroxenite from Sor Jougdan, Seve Nappe Complex, Sweden: Implications for UHP Metamorphism of Allochthons in the Scandinavian Caledonides. J. Metam. Geol. 2016, 34, 103-119. [CrossRef]

87. Corfu, F.; Andersen, T.B. U-Pb Ages of the Dalsfjord Complex, SW Norway, and Their Bearing on the Correlation of Allochthonous Crystalline Segments of the Scandinavian Caledonides. Int. J. Earth Sci. 2002, 91, 955-963. [CrossRef]

88. Johnston, S.; Hacker, B.R.; Andersen, T.B. Exhuming Norwegian Ultrahigh-Pressure Rocks: Overprinting Extensional Structures and the Role of the Nordfjord-Sogn Detachment Zone. Tectonics 2007, 26, TC5001. [CrossRef]

89. Andersen, T.B.; Skjerlie, K.P.; Furnes, H. The Sunnfjord Melange, Evidence of Silurian Ophiolite Accretion in the West Norwegian Caledonides. J. Geol. Soc. Lond. 1990, 147, 59-68. Available online: https://jgs-lyellcollection-org.ezproxy.uio.no/content/147/1/59 (accessed on 28 November 2021). [CrossRef] 
90. Eide, E.A.; Torsvik, T.H.; Andersen, T.B.; Arnaud, N.O. Early Carboniferous Unroofing in Western Norway: The Tale of Alkali Feldspar Thermochronology. J. Geol. 1999, 107, 353-374. [CrossRef]

91. Furnes, H.; Skjerlie, K.P.; Pedersen, R.B.; Andersen, T.B.; Stillman, C.J. The Solund-Stavfjord Ophiolite Complex and Associated Rocks, West Norwegian Caledonides: Geology, Geochemistry and Tectonic Environment. Geol. Mag. 1990, 127, $209-224$. [CrossRef]

92. Jakob, J.; Andersen, T.B.; Mohn, G.; Kjøll, H.J.; Beyssac, O. A Revised Tectono-Stratigraphic Scheme for the Scandinavian Caledonides and Its Implications for Our Understanding of the Scandian Orogeny. Geol. Soc. Am. Spec. Paper. In New Developments in the Appalachian-Caledonian-Variscan Orogen; Kuiper, Y., Murphy, B., Nance, D., Strachan, R., Thompson, M., Eds.; Geological Society of America: Boulder, CO, USA; Available online: https://pubs.geoscienceworld.org/gsa/books/book/ 2335/New-Developments-in-the-Appalachian-Caledonian (accessed on 28 November 2021).

93. Lindahl, I.; Nilsson, L.P. Geology of the Soapstone Deposits of the Linnajavri Area, Hamarøy, Nordland, North Norwegian Caledonides-Norway's Largest Reserves of Soapstone. In Geological Survey of Norway Special Publication; Slagstad, T., Ed.; Geological Survey of Norway: Trondheim, Norway, 2008; Volume 11, pp. 19-35. Available online: https://www.ngu.no/upload/ Publikasjoner/Special\%20publication/SP11_LO.pdf (accessed on 28 November 2021).

94. Kolstrup, M.L.; Maupin, V. A Proterozoic Boundary in Southern Norway Revealed by Joint-Inversion of P-Receiver Functions and Surface Waves. Precamb. Res. 2013, 238, 186-198. [CrossRef]

95. Gilotti, J.A.; Kumpulainen, R. Strain Softening Induced Ductile Flow in the Särv Thrust Sheet, Scandinavian Caledonides. J. Struct. Geo. 1986, 8, 441-455. [CrossRef]

96. Andréasson, P.-G.; Svenningsen, O.; Johansson, I.; Solyom, Z.; Xiaodan, T. Mafic Dyke Swarms of the Baltica-Iapetus Transition, Seve Nappe Complex of the Sarek Mts., Swedish Caledonides. GFF 1992, 114, 31-45. [CrossRef]

97. Svenningsen, O.M. Tectonic Significance of the Meta-Evaporitic Magnesite and Scapolite Deposits in the Seve Nappes, Sarek Mts., Swedish Caledonides. Tectonophys 1994, 231, 33-44. [CrossRef]

98. Svenningsen, O.M. Onset of Seafloor Spreading in the Iapetus Ocean at 608 Ma Precise Age of the Sarek Dyke Swarm, Northern Swedish Caledonides. Precambrian Res. 2001, 110, 241-254. [CrossRef]

99. Gasser, D.; Jeřábek, P.; Farber, C.; Stünitz, H.; Menegon, L.; Corfu, F.; Erembert, M.; Whitehouse, M.J. Behaviour of Geochronometers and Timing of Metamorphic Reactions during Deformation at Lower Crustal Conditions: Phase Equilibrium Modelling and U-Pb Dating. J. Metamorph. 2015, 33, 513-534. [CrossRef]

100. Kjøll, H.-J. Neoproterozoic to Lower Paleozoic Evolution of the Pre-Caledonian Magma-Rich Margin of Baltica. Ph.D. Thesis, University of Oslo, Oslo, Norway, 2019; 242p. Available online: https://www.duo.uio.no/handle/10852/70340 (accessed on 28 November 2021).

101. Kjøll, H.J. Late Neoproterozoic Basin Evolution of the Magma Rich Iapetus Margin of Baltica. Nor. J. Geol. 2020, 100, 32. [CrossRef]

102. Rehnström, E.F.; Corfu, F. Paleoproterozoic U-Pb Ages of Allochthonous and Autochthonous Granites from the Northern Swedish Caledonides-Regional and Palaeogeographical Implications. Precamb. Res. 2004, 132, 363-378. [CrossRef]

103. Rehnström, E.F.; Corfu, F.; Torsvik, T.H. Evidence of a Late Precambrian (637 Ma) Deformational Event in the Caledonides of Northern Sweden. J. Geol. 2002, 110, 591-601.

104. Kirkland, C.L.; Bingen, B.; Whitehouse, M.J.; Beyerd, E.; Griffin, W.L. Neoproterozoic Palaeogeography in the North Atlantic Region: Inferences from the Akkajaure and Seve Nappes of the Scandinavian Caledonides. Precamb. Res. 2011, 186, 127-146. [CrossRef]

105. Kirkland, C.L.; Daly, J.S.; Whitehouse, M.J. Tectonic Evolution of the Arctic Norwegian Caledonides from a Texturally- and Structurally-Constrained Multi-Isotopic (Ar-Ar, Rb-Sr, Sm-Nd, U-Pb) Study. Am. J. Sci. 2007, 307, 459-526. [CrossRef]

106. Kirkland, C.L.; Daly, J.S.; Chew, D.M.; Page, L. The Finnmarkian Orogeny Revisited: An Isotopic Investigation of the Eastern Kalak Nappe Complex, Arctic Norway. Tectonophys 2008, 460, 158-177. [CrossRef]

107. Corfu, F.; Roberts, R.J.; Torsvik, T.H.; Ashwal, L.D.; Ramsay, D.M. Peri-Gondwanan Elements in the Caledonian Nappes of Finnmark, Northern Norway: Implications for the Paleogeographic Framework of the Scandinavian Caledonides. Am. J. Sci. 2007, 307, 434-458. [CrossRef]

108. Paulsson, O.; Andréasson, P.-G. Attempted Break-up of Rodinia at 850 Ma: Geochronological Evidence from the Seve-Kalak Superterrane, Scandinavian Caledonides. J. Geol. Soc. Lond. 2002, 159, 751-761. Available online: https://jgs.lyellcollection.org/ content/159/6/751 (accessed on 28 November 2021). [CrossRef]

109. Maijer, C.; Verschure, R.H. Petrology and Isotope Geology of the Hunnedalen Monzonoritic Dyke Swarm, SW Norway: A Possible Late Expression of Egersund Anorthosite Magmatism. Nor. Geol. Unders. Bull. 1998, 434, 83-107. Available online: https://openarchive.ngu.no/ngu-xmlui/handle/11250/2674084 (accessed on 28 November 2021).

110. Kullerud, K.; Stephens, M.; Zachrisson, E. Pillow Lavas as Protoliths for Eclogites: Evidence from a Late Precambrian-Cambrian Continental Margin, Seve Nappes, Scandinavian Caledonides. Contrib. Min. Pet. 1990, 105, 1-10. [CrossRef]

111. Stølen, L.K. The Rift-Related Mafic Dyke Complex of the Rouhkunborri Nappe, Indre Troms, Northern Norwegian Caledonides. GFF 1994, 116, 121-131. [CrossRef]

112. Krabbendam, M.; Wain, A.; Andersen, T.B. Pre-Caledonian Granulite and Gabbro Enclaves in the Western Gneiss Region, Norway: Indications of Incomplete Transition at High Pressure. Geol. Mag. 2000, 137, 235-255. [CrossRef]

113. Vrijmoed, J.C.; Podladchikov, Y.Y.; Andersen, T.B.; Hartz, E.H. An Alternative Model for Ultra-High Pressure in the Svartberget Fe-Ti Garnet-Peridotite, Western Gneiss Region, Norway. Eur. J. Min. 2009, 21, 1119-1133. [CrossRef] 
114. Majka, J.; Be'eri-Shlevin, Y.; Gee, D.G.; Ladenberger, A.; Claesson, S.; Konečný, P.; Klonowska, I. Multiple Monazite Growth in the Åreskutan Migmatite: Evidence for a Polymetamorphic Late Ordovician to Late Silurian Evolution in the Seve Nappe Complex of West-Central Jämtland, Sweden. J. Geosci. 2012, 57, 3-23. [CrossRef]

115. Li, B.; Massonne, H.-J.; Zhang, J. Evolution of a Gneiss in the Seve Nappe Complex of Central Sweden-Hints at an Early Caledonian, Medium-Pressure Metamorphism. Lithos 2020, 376, 105746. [CrossRef]

116. Baird, G.B.; Figg, S.A.; Chamberlain, K.R. Intrusive Age and Geochemistry of the Kebne Dyke Complex in the Seve Nappe complex, Kebnekaise Massif, Arctic SWEDEN Caledonides. GFF 2014, 136, 556-570. [CrossRef]

117. van Roermund, H.; Majka, J.; Janák, M.; Klonowska, I. Orogenic (Spinel and Garnet) Peridotites and High and Ultrahigh Pressure Rocks of the Seve Nappe Complex, N. Jämtland, S. Västerbotten, Central Swedish Caledonides. In Proceedings of the 12th International Eclogite Conference, Pre-Conference Excursion Guide, Åre, Sweden, 20-29 August 2017.

118. Dalquist, P. Late Ordovician (Hirnantian) Depositional Pattern and Sea-Level Change in Shallow Marine to Shoreface Cycles in Central Sweden. Geol. Mag. 2004, 141, 605-616. [CrossRef]

119. Brueckner, H.K. Sinking Intrusion Model for the Emplacement of Garnet-Bearing Peridotites into Continent Collision Orogens. Geology 1998, 26, 631-634. [CrossRef]

120. Scambelluri, M.; Pettke, T.; van Roermund, H.L.M. Majoritic Garnets Monitor Deep Subduction Fluid Flow and Mantle Dynamics Geology 2008, 36, 59-62. [CrossRef]

121. Slama, J.; Pedersen, R.B. Zircon Provenance of SW Caledonian Phyllites Reveals a Distant Timanian Sediment Source. J. Geol. Soc. Lond. 2015, 172, 465-478. Available online: https://jgs-lyellcollection-org.ezproxy.uio.no/content/172/4/465 (accessed on 28 November 2021). [CrossRef]

122. Kühn, A.; Glodny, J.; Austrheim, H.; Råheim, A. The Caledonian Tectono-Metamorphic Evolution of the Lindås Nappe: Constraints from U-Pb, Sm-Nd and Rb-Sr Ages of Granitoid Dykes. Nor. J. Geol. 2000, 82, 45-57.

123. Lundmark, A.M.; Corfu, F. Age and Origin of the Årdal Dike Complex, SW Norway: False Isochrons, Incomplete Mixing, and the Origin of Caledonian Granites in Basement Nappes. Tectonics 2007, 26, TC2007. [CrossRef]

124. Andréasson, P.-G. The Continent-Ocean (Seve-Köli) Boundary in the Sarek-Padjelanta Mts. Revisited: Swedish Caledonides. GFF 2020, 142, 125-138. [CrossRef]

125. Pedersen, R.B. Dunning, GR. Provenance of Turbiditic Cover to the Caledonian Solund-Stavfjord Ophiolite from U-Pb Single Zircon Dating. J. Geol. Soc. Lond. 1993, 150, 673-676. [CrossRef]

126. Corfu, F.; Torsvik, T.H.; Andersen, T.B.; Ashwal, L.; Ramsay, D.M.; Roberts, R.J. Early Silurian Mafic-Ultramafic and Granitic Plutonism in Contemporaneous Flysch, Magerøy, Northern Norway: U-Pb Ages and Regional Significance. J. Geol., Soc. Lond. 2006, 163, 291-301. Available online: https:/ /jgs-lyellcollection-org.ezproxy.uio.no/content/163/2/291 (accessed on 28 November 2021). [CrossRef] 